\title{
A New Gob-Side Entry Layout for Longwall Top Coal Caving
}

\author{
Guorui Feng ${ }^{1}$, Pengfei Wang ${ }^{1, *}$ (i) and Yoginder P. Chugh ${ }^{2,3}$ \\ College of Mining Engineering, Taiyuan University of Technology, Taiyuan 030024, China; fguorui@163.com \\ 2 Mining and Mineral Resources Engineering, Southern Illinois University, Carbondale, IL 62901, USA; \\ ypchugh1940@gmail.com \\ 3 Fellow, National Academy of Inventors, Tampa, FL 33612-9445, USA \\ * Correspondence: shengshikuangdaren@163.com
}

Received: 17 April 2018; Accepted: 15 May 2018; Published: 18 May 2018

\begin{abstract}
In China, gob-side entry is typically located one pillar-width (less than $5 \mathrm{~m}$ ) away from the previously mined-out panel in a conventional longwall panel using top coal caving (LTCC). Design of gob-side entries is a challenge due to the complex dynamic loading process during their service life. A new gob-side entry (NGE) design practice is presented here for Zhenchengdi Colliery, which has many advantages. A theoretical analysis is presented followed by numerical modeling. The modeling included the double-yield constitutive model for gob behavior to analyze the stress environment for the gob-side entry with validation through field observations. The results indicate that pre-mining stress within gob occurred $51 \mathrm{~m}$ away from the gob edge. The NGE is located within a destressed zone in the entire panel system, which results in lower side abutment pressure for the adjacent panel to be mined. The stress concentration around the gob edge near the gob-side entry is relatively low (less than 0.1) compared with the other side of the gob. Field observations indicate that: (1) a simple support design, i.e., steel sets with wire mesh on the top, can maintain ground control and ventilation during active mining; (2) the periodic weighting interval is 9-12 m; (3) the length of the block "B" which "protects" the gob-side entry is 10-13 m; (4) stress distribution formula for the elevating section is derived; and (5) the roof pressure of the gob-side entry is much smaller than non-gob side entry and is smaller than the pre-mining stress. Deformation data of the gob-side entry shows that both roof-to-floor and rib-to-rib convergences are smaller than for the non-gob-side entry with an improved overall stress environment. Theoretical analysis, numerical modeling, and field observation are consistent, which validates the scientific foundations of the new technology.
\end{abstract}

Keywords: gob-side entry; angle of break; double-yield model; panel geometry

\section{Introduction}

Mechanized, single-cut retreat longwall mining with top coal caving (LTCC) is widely used for underground coal extraction around the world. Development entries, or gateroads, play an important safety and productivity role in mining operations in LTCC. A wide pillar is left unmined between adjacent panels to ensure stability of the entry, as shown in Figure 1. This, however, can lead to low coal recovery. To solve this problem, the gob-side entry approach has been proposed by researchers [1-14]. As shown in Figure 2, it is a combination of a gateroad, pillar, and gob, which is a typical panel layout with slender pillar or artificial pillar or wall. Gob-side entry are of two types [2]: (i) gob-side entry driven in a new panel with only a slender (often less than $5 \mathrm{~m}$ ) pillar away from the gob, as shown in Figure 2a; and (ii) retained gob-side entry (Figure 2b), which is an entry of a previous panel retained as the entry for a future panel by constructing an artificial wall along the gob edge of the previous mined-out panel [3,4]. 


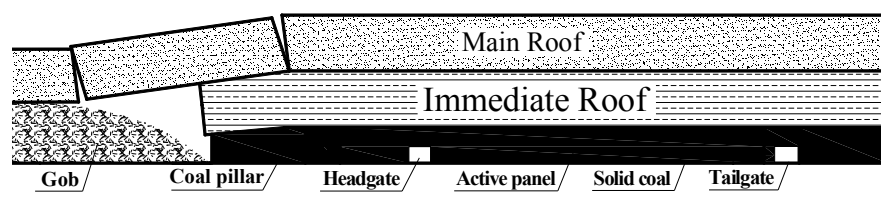

Figure 1. A conventional development entry design in LTCC.

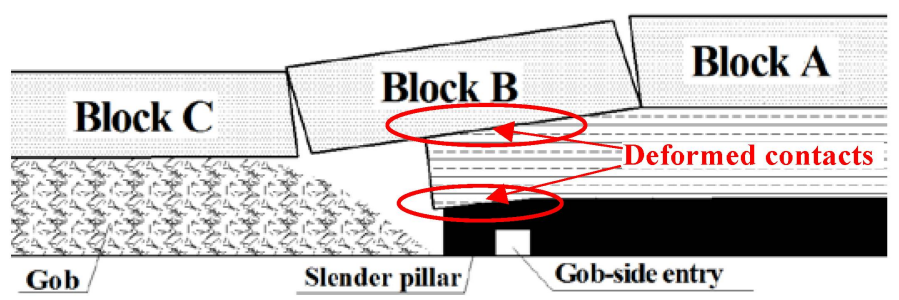

(a)

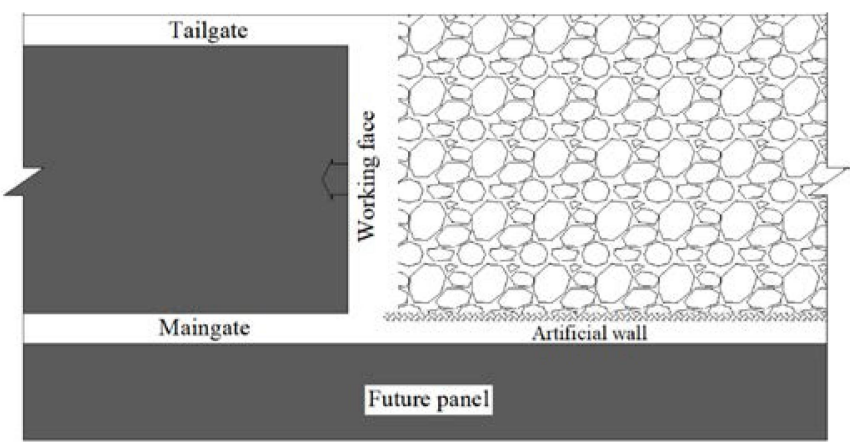

(b)

Figure 2. A gob-side entry layout [2]. (a) Gob-side entry driven in a new panel; and (b) entry of a previous panel retained for a future panel.

After excavation of a panel, the stress on the solid coal on the right (Figure 3) can be divided into four zones [2,5]: I-de-stressed yield zone, II-over-stressed plastic zone, III-over-stressed elastic zone, and IV-pre-mining vertical stress zone. Gob-side entry is located within zone I to avoid a high stress concentration in zones II and III, and to avoid a large size pillar in zone IV, which would result in low recovery. Gob-side entry makes use of the side abutment pressure redistribution to locate gob-side entry in the de-stressed zone within the solid coal, i.e., zone I in Figure 3.

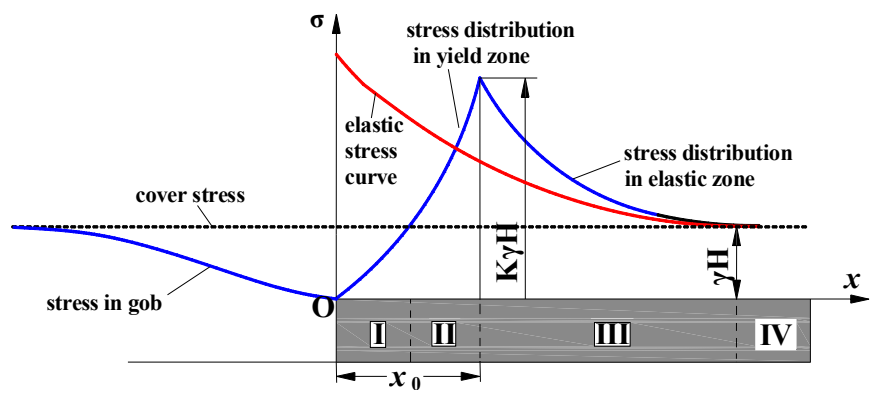

Figure 3. Stress distribution after extraction of an LTCC panel [2].

Yan [3] stated that the de-stressed zone occurs 0-7 $\mathrm{m}$ and the main roof will form the stable masonry structure to provide a low-stress environment for gob-side entry. He suggested driving the gob-side entry along the gob with a $5 \mathrm{~m}$ slender pillar. Li [6] noted that a gob-side entry with a $6 \mathrm{~m}$ 
wide coal pillar based on numerical modeling was employed in LTCC in mining a $15 \mathrm{~m}$ thick coal seam in the Tashan mine of Datong Coal Group in China. Li [7], on the other hand, argued that high pressure would also occur on the edge of the solid coal and a structural model was built, as shown in Figure 4. A formula for computing the width of "inner stress field" $S_{1}$ was derived:

$$
S_{1}=\frac{6 L\left(\sum_{i=1}^{n} h_{i}\right)^{2} \gamma \sqrt{2 \sigma_{t} /\left(q_{n}\right)_{1}}}{G_{0} y_{0}}
$$

where $L$ is the panel width, $(\mathrm{m}) ; h_{i}$ is the thickness of the $i$ th roof main stratum, $(\mathrm{m}) ; \gamma$ is the unit weight of the main roof, $\left(\mathrm{N} / \mathrm{m}^{3}\right) ; \sigma_{t}$ is the tensile strength, $(\mathrm{Pa}) ; G_{0}$ is the stiffness of coal on the left of caving line, $(\mathrm{Pa}) ; y_{0}$ is the average compression of the slender pillar; $\left(q_{n}\right)_{1}$ is the loading of the $n$th roof strata in ascending order above the key stratum (including the dead weight of the lowest key stratum), and $\left(q_{n}\right)_{1}$ is expressed as:

$$
\left(q_{n}\right)_{1}=\frac{E_{1} h_{1}^{3}\left(\gamma_{1} h_{1}+\gamma_{2} h_{2}+\cdots+\gamma_{n} h_{n}\right)}{E_{1} h_{1}^{3}+E_{2} h_{2}^{3}+\cdots+E_{n} h_{n}^{3}}
$$

where $E_{i}$ is modulus of elasticity of individual layers, [Pa].

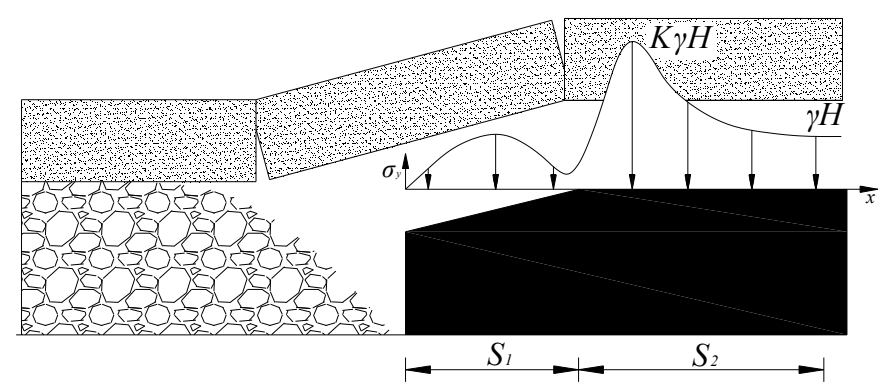

Figure 4. Structural model for abutment pressure distribution [7].

It was demonstrated that stability and load-bearing characteristics of the slender pillar depend on several factors, including mechanical properties of the roof strata, cover depth, panel geometry, etc. Yan [3] further indicated that the bearing capacity of the slender pillar would decrease because both edges of the pillar are fractured. Due to the effect of moving the front abutment pressure with the advance of an active panel, the pillar along the gob-side would be more deformed and fractured. With the fracturing of the main roof, the pressure and deformation of host rock will increase rapidly and it would be more difficult to keep the gob-side entry stable. Therefore, the slender coal pillar is still subjected to the loading resulting from the fractured main roof, even though the main roof and solid coal (where they are touching) is more or less compressed, deformed, or crushed, as shown in Figure 2a.

In order to increase the stability and load-bearing capability of the gob-side entry, several different types of artificial walls were proposed [3,8-11]. Many destressing technologies for the gob-side entry, along with supplementary supports were suggested [12]. Zhang [8] proposed a roadside backfill body (RBB) using high-water quick-setting materials for highly-gassy multi-entry for LTCC. RBB thicknesses of $1.0 \mathrm{~m}, 1.2 \mathrm{~m}, 1.5 \mathrm{~m}, 1.8 \mathrm{~m}$, and $2.0 \mathrm{~m}$ were analyzed using numerical models and it was eventually determined that the best choice was $1.5 \mathrm{~m}$. Yang [9] proposed a similar approach. Zhang [10,11] presented an artificial wall built along the gob using a cementing material, fly ash, detrital refuse, and concrete. Tan [3] proposed a new type of artificial composite wall that consists of an upper flexible layer and a lower hard layer which can sustain large compression and provide strong supporting intensity.

Overall, Zhang's [8] and Zhang's [10,11] methods are positive approaches which intend to provide high abutment-load carrying capacity of the artificial pillar, while Tan's [3] artificial pillar 
is a "semi-positive" and "semi-passive" approach, the pillar can deform to some extent with the deformation and rotation of the roof beam structure. No matter what pillar it is, natural or artificial, the optimum width of the slender pillar or artificial wall should be designed based on the expected abutment pressure [2].

The gob-side entry designed above will still cause gateroads and slender pillars to be subjected to a complex dynamic loading environment during their service life [13]. Conventional roof supports may not be adequate to meet the requirements for mining operations and supplementary supports, such as ladder beam, counter-pulled bolts, and variations of pipe-shed support systems must be used for ground control, which can result in high production costs. Designing a gob-side entry still remains relatively complicated and challenging at present.

This paper proposes a new and relatively simple approach for gob-side entry design for LTCC. In this approach to the gob-side entry, mining-induced stress distribution should be made most of, the complex dynamic loading environment must be avoided, and support design should be simpler.

The arrangement is listed as follows: In Section 2, the geological, geotechnical settings, and mining conditions and circumstances are presented. In Section 3, the new approach is introduced. In Section 4, numerical modelling, incorporating the angle of break and a double-yield model of the gob model is then carried out. In Section 5, field testing and observation is conducted. In Section 6, pros and cons of the approach are discussed. Conclusions are listed according to the study of the paper in Section 7.

\section{Engineering Background of the Case Study Mine}

The analysis is based on the mining conditions of the 18111 and 18111-1 panels of the \#8 coal seam in Zhenchengdi Colliery, Shanxi Province, China. The panels are $600 \mathrm{~m}$ long along the strike and $120 \mathrm{~m}$ wide along the dip. The average coal seam thickness is $5 \mathrm{~m}$ thick. The average cover depth and seam dip angle are $200 \mathrm{~m}$ and $8^{\circ}$, respectively. The generalized stratigraphy for panel 18111- 1 is shown in Figure 5 in descending order. The mining height is $2.3 \mathrm{~m}$, and the caving height is $2.7 \mathrm{~m}$. All entry cross-sections are trapezoidal, $2.8 \mathrm{~m}$ wide on the top, $3.6 \mathrm{~m}$ wide on the bottom, and $2.5 \mathrm{~m}$ high (Figure $6 a, b)$. The major tectonic structure in the area is a simple mono-synclinal structure.

\begin{tabular}{|c|c|c|}
\hline Thickness/m & Depth/m & Lithology \\
\hline 6.41 & 182.08 & Silty mudstone \\
\hline 3.66 & 188.49 & Siltstone \\
\hline 1.43 & 192.15 & Silty mudstone \\
\hline 2.33 & 193.58 & 7\# coal seam \\
\hline 2.31 & 195.91 & Siltstone \\
\hline 1.79 & 198.21 & Limestone \\
\hline 5.00 & 200.00 & 8\# coal seam \\
\hline 1.10 & 205.00 & Fine-grained sandstone \\
\hline 1.43 & 206.10 & Mudstone \\
\hline 0.25 & 207.53 & Coal \\
\hline 2.19 & 207.78 & Silty mudstone \\
\hline
\end{tabular}

Figure 5. Generalized stratigraphic column. 


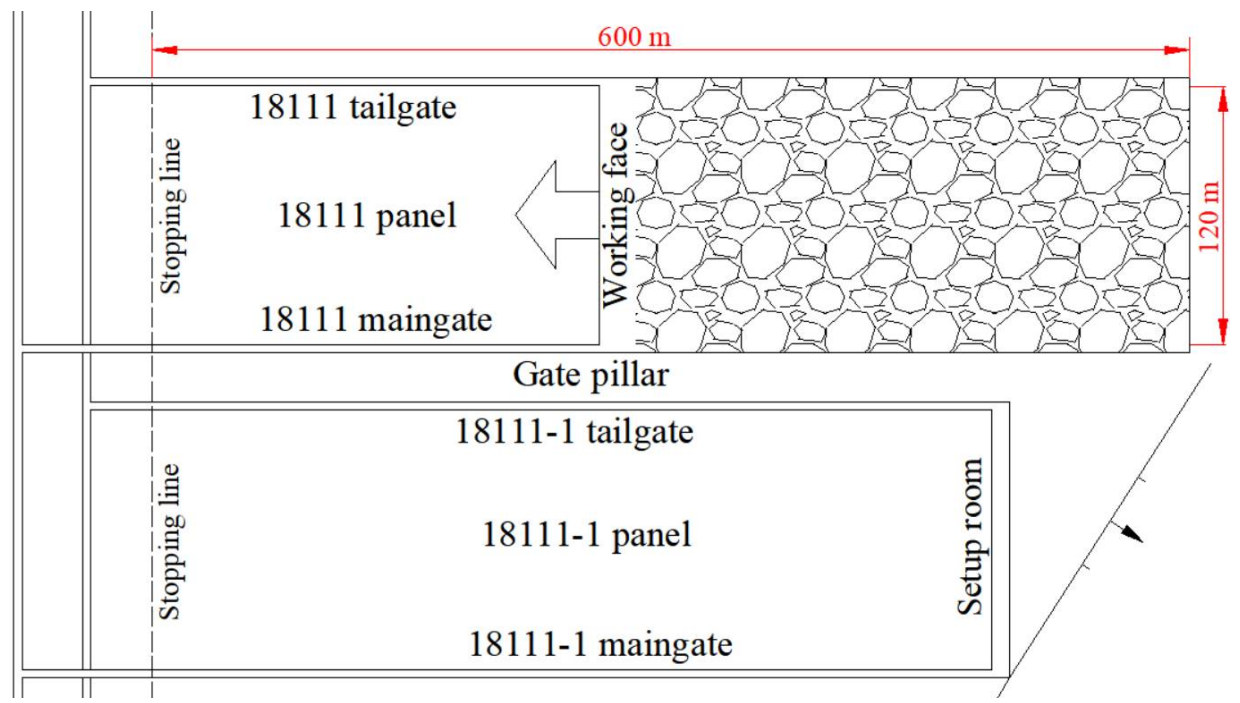

(a)

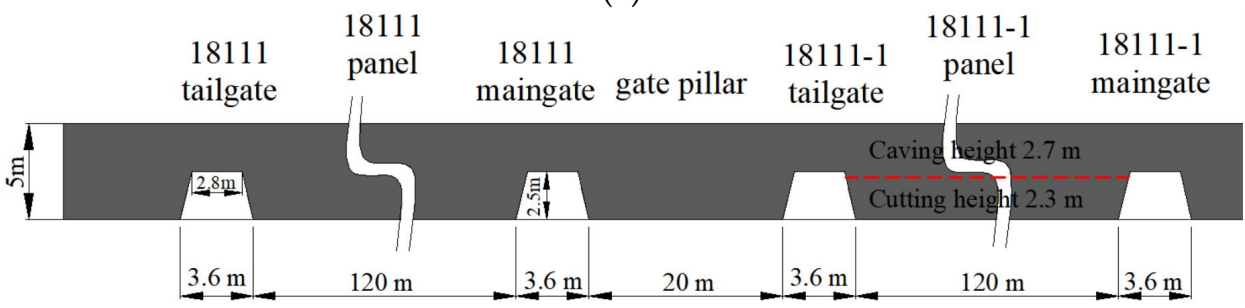

(b)

Figure 6. A conventional development entry layout. (a) Plan view; and (b) section view.

\section{A New Gob-Side Entry (NGE)}

The proposed new gob-side entry (NGE) is illustrated in Figure 7. The development entries on either end of the panel are located at different elevations [14]. For the 18111 panel, the tailgate is driven along the floor while the maingate is driven along the roof. Thus, the longwall face has a gradually elevating section on one end of the 18111 panel. The elevating section slope is incrementally increased by adjusting the inclination of each section of the armored face conveyor (AFC), shields, and other production machines. Figure 7c shows that the length and inclination of each AFC section are typically $1.5 \mathrm{~m}$ and $3^{\circ}$ [15]. For the adjacent 18111-1 panel, the tailgate, i.e., the gob-side entry, is located at the floor level and is offset horizontally with respect to the maingate of the 18111 panel. Similarly, the maingate of the 18111-1 panel is driven along the roof, thus forming the same geometry with the 18111 panel. The two adjacent panels are extracted sequentially. Therefore, there are several locations for the gob-side entry, as shown in Figure 8. The case study mine decided to select Entry 1 to extract more coal. The stress distribution for this new configuration is illustrated in Figure 9.

Compared with the conventional side abutment pressure distribution in LTCC (Figure 3), two additional zones are observed for this new geometry: zone V, stress-free zone; and zone VI, de-stressed gob edge zone. Typically, 3-6 m away from the gob edge to the gob, caved rocks are hardly seen. That is the reason for naming zone $\mathrm{V}$ the stress-free zone, and the concept is similar to the wisdom that the safest place in a room during an earthquake is a corner where a bridge protective structure is likely to form. 


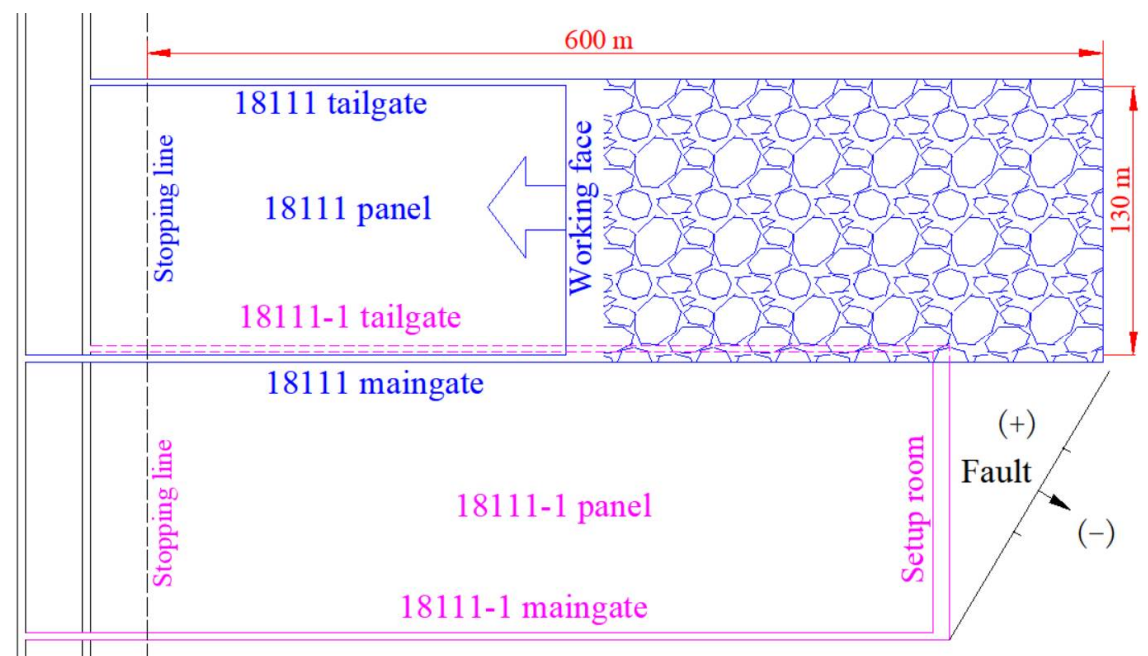

(a)

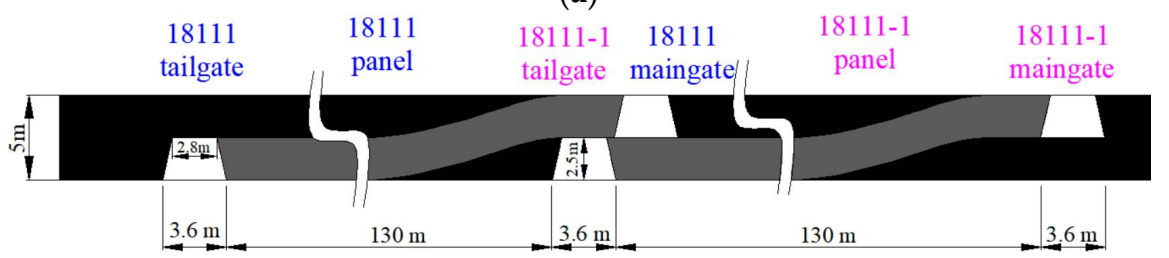

(b)

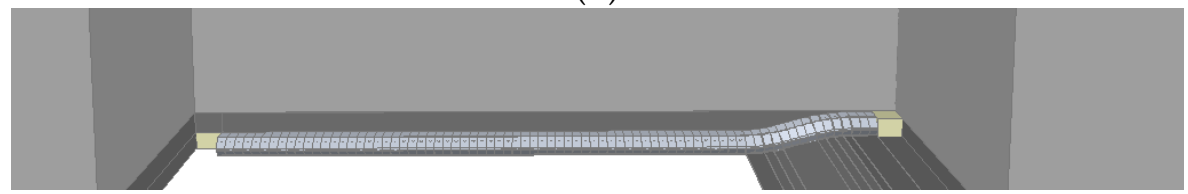

(c)

Figure 7. A diagram of NGE split-level development entry. (a) Plan view; (b) section view; and (c) 3-D view.

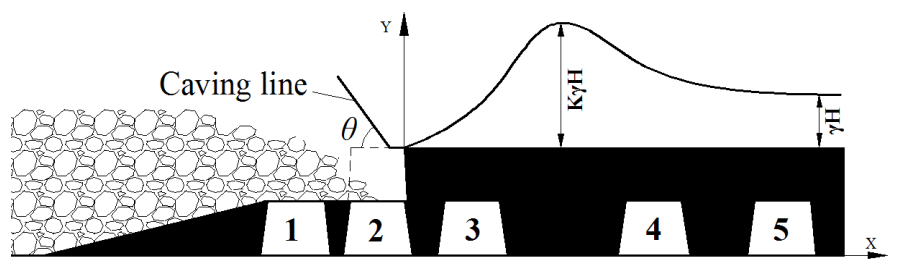

Figure 8. Different location options for the development entry.

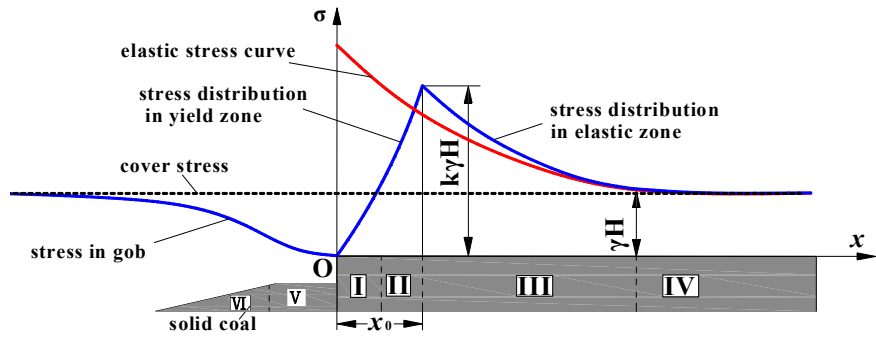

Figure 9. Stress distribution for the NGE geometry (after Qian) [2].

The proposed NGE approach has many advantages: (i) increased recovery of over 10\% [16]; (ii) reduced risk of spontaneous combustion [17]; (iii) the 18111-1 tailgate (the gob-side entry) is located in 
the de-stressed zone along the gob edge, i.e., zone V in Figure 9, and this zone is de-stressed and is only subjected to the load of caved immediate roof fragments below the main roof protective structure after the 18111 panel is mined out; and (iv) the complexity in determining the size of the slender pillar is avoided, and no artificial wall needs to be constructed, which reduces the mining cost.

Many researchers have focused on locating the gob-side development entry in zone I shown in Figure 3. However, another de-stressed zone was overlooked and that was the gob. Yavuz [18] derived the formula for the stress at a distance $x$ in the gob below:

$$
\sigma_{X}=\frac{10.39 \sigma_{c}^{1.042}(b-1)\left(S_{x}+\frac{0.4 m}{c_{3} m+c_{4}}-0.05 m^{1.2}\right)}{\left(m b^{8.7}-0.05 m^{1.2} b^{7.7}\right)-b^{8.7}\left(S_{x}+\frac{0.4 m}{c_{3} m+c_{4}}-0.05 m^{1.2}\right)}
$$

where $\sigma_{t}$ is the compressive strength (MPa); $b$ is the bulking factor of the caved roof; $S_{x}$ is the subsidence of surface at distance $x(\mathrm{~m}) ; x$ is the horizontal distance from the origin $(\mathrm{m})$, which is located at the center of the subsidence profile; and $c_{3}$ and $c_{4}$ are coefficients depending on lithology.

If the vertical expansion and sagging of the strata in the fractured zone are ignored, then Equation (3) is reduced to:

$$
\sigma_{X}=\frac{10.39 \sigma_{c}^{1.042}(b-1)}{b^{8.7}\left(m-S_{x}\right)}
$$

Based on these equations, an in-depth study of a number of parameters, including the bulking factor of the caved material, the strength of immediate and main roof strata, the excavation height, etc., was performed [18]. The results suggest that for all variations of those parameters, the stress for the gob edge is always less than any other parts in the entire panel layout system and is far less than the pre-mining stress.

In the NGE, stress distribution for the 18111-1 panel after the excavation of the 18111 panel and is shown in Figure 10 (after Brady [19]) and Figure 11. As 18111-1 tailgate inner offset more than one entry with respect to the 18111 maingate (Figure $7 \mathrm{~b}$ ), the solid coal mass on the right of the 18111 maingate influenced by the side abutment pressure is located approximately $4 \mathrm{~m}$ away from the gob-side entry. Hence, the side abutment pressure "steps over" the gob-side entry and the stress concentration that occurs at the T-junction due to the superposition of the front abutment, and side abutment pressure is located within the solid coal of the 18111-1 panel. Thus, the 18111-1 tailgate is independent of both side abutment pressure and front abutment pressure.

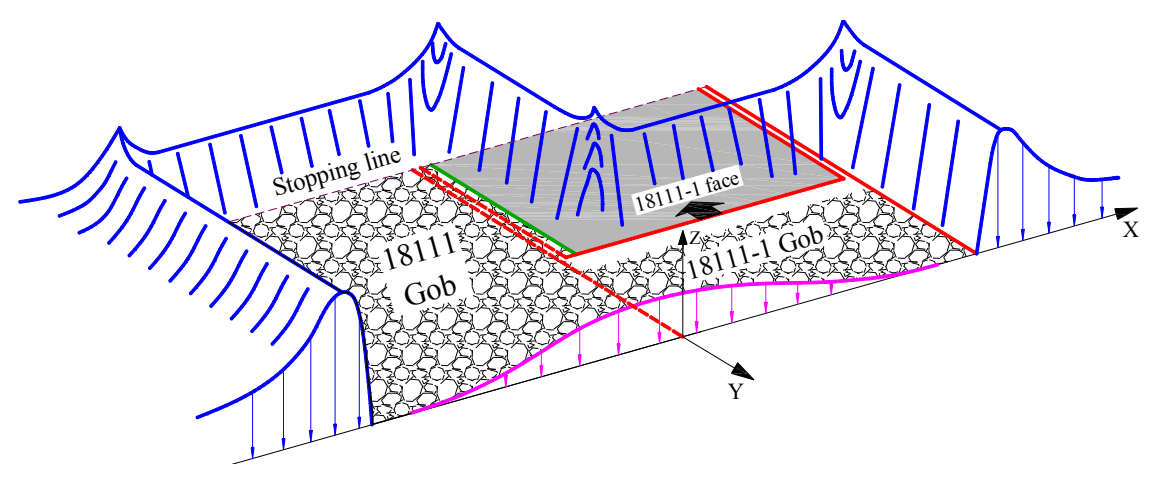

Figure 10. Stress distribution for the 18111-1 panel after the excavation of the 18111 panel (after Brady) [19]. 


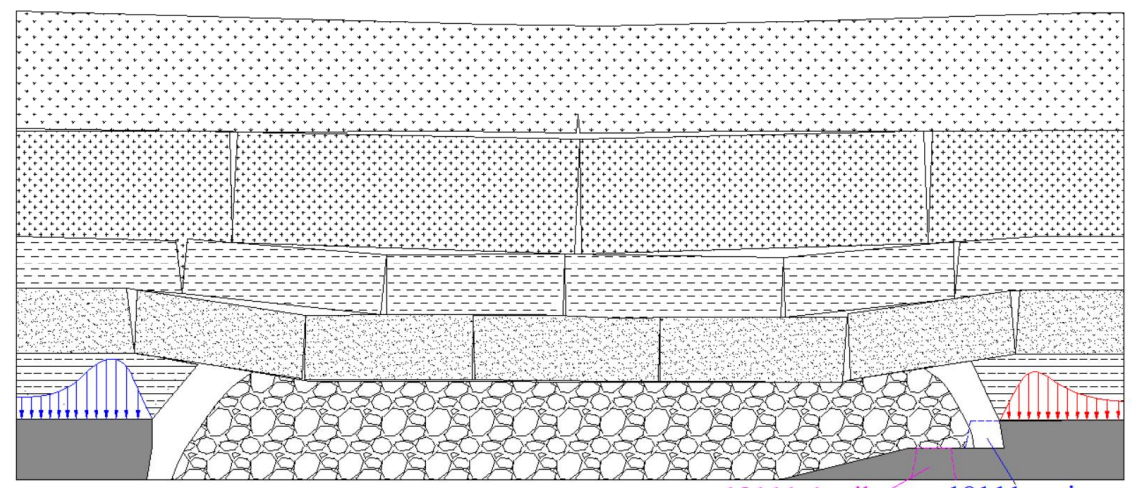

18111-1 tailgate 18111 maingate

Figure 11. Side abutment pressure characteristics for the NGE.

The fall height for the caving rocks above the elevating section is relatively small compared with the other parts of the gob. Esterhuizen [20] indicated that, as the fall height reduces, the potential for fragments to rotate diminishes and the bulking factor of the caved rocks is reduced. Thus, the caved rock fragments have a low void ratio and are able to accept the loads more quickly [21]. Therefore, pressure transferred to the abutment close to the elevating section should be less, resulting in lower side abutment pressure for the adjacent panel. Since the geometry of the panel is asymmetrical, the stress distribution must be consequently asymmetrical. Side abutment pressure on the right side (red line) is gentler than that on the left (blue line).

On the other hand, compression arches commonly develop across longwall panels due to coal extraction, provided the panel is narrow enough or deep enough for both ends of the arch to span the panel width and bear on rock. These arches are zones of tangential compressive stress where some of the weight of the overburden overlying the arch can be transferred onto the abutments. Some, or all, of the downward deflected rock under the arch will bear on the collapsed rock under the arch. If the width of a longwall panel is too wide or too shallow for the stress arch to span the panel width, a smaller stress arch will form, with one end of the arch bearing on and compressing the collapsed gob [22]. However, since coal mines in China are getting deeper, the critical panel width for most longwall panels is not reached. Therefore, the full weight of the overburden strata is not transferred onto the gob due to bridging of strata between abutments [18]. That is not the case for NGE, fortunately. Since conventional rectangular pillars between adjacent panels are eliminated, the roof strata above the adjacent panels are connected and deform as a single unit similar to a super-critical LTCC panel, as shown in Figure 12. Caved rock fragments are more compacted and more overburden weight is picked up by the gob rather than the abutments leading to lower side abutment pressure for the adjacent active or future panel. Lastly, different locations for the gob-side entry generate different ground control issues. The effects of the different development entry locations on the stress distribution are shown in Figure 13.

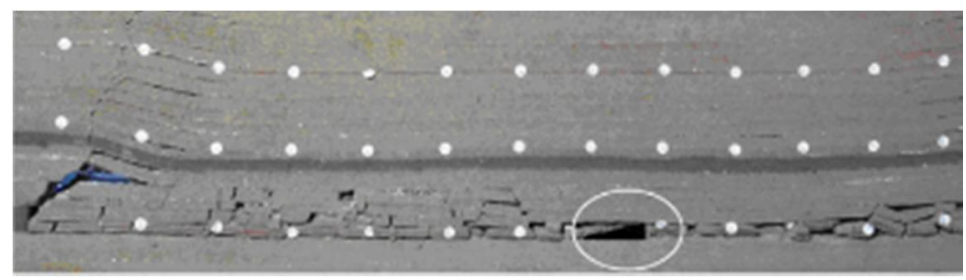

Figure 12. Roof strata movements and deformation characteristics for the NGE. 


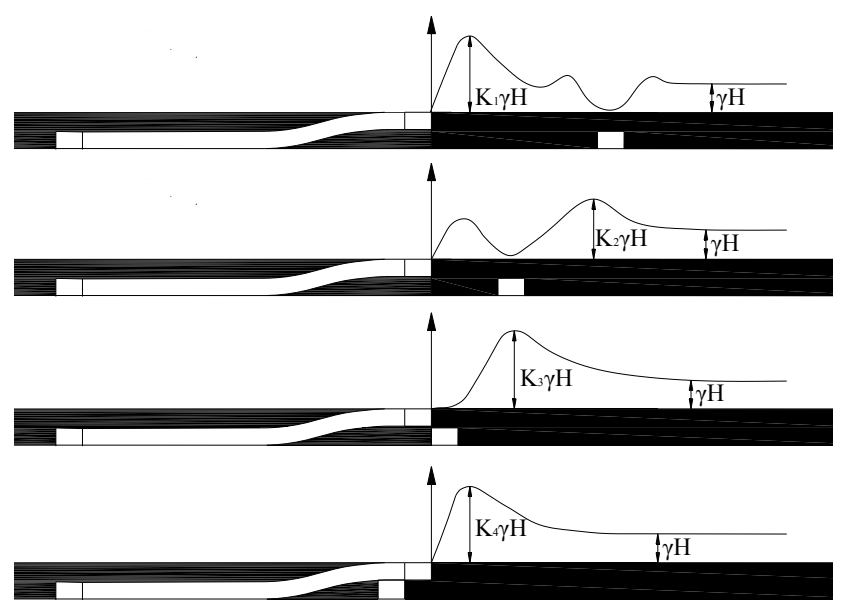

Figure 13. Stress distribution for the NGE geometries.

According to the slip line field theory [23], the floor in Zone I in Figure 14a is in the active Rankine state, which tends to move toward the excavation. The angle formed by the horizontal line and slip-line is $45^{\circ}+/-\phi / 2$, with the major principal stress depending upon the sign convention; Zone III is in the active Rankine state, the angle formed by the horizontal line and slip-line is $45^{\circ}-/+\phi / 2$; Zone II is the transition zone and the curve " $\mathrm{AB}$ " may be taken as the logarithmic spiral with the equation:

$$
r=r_{0} e^{\theta \tan \varphi}
$$

where, $r$ is the radius of the spiral, $r_{0}$ is the length of $\mathrm{OA}$ (i.e., starting radius at $\left.\theta=0\right)(\mathrm{m}) ; \theta$ is the angle formed by $\mathrm{OA}$ and $\mathrm{OB}$ (i.e., $r$ and $\left.r_{0}\right)\left({ }^{\circ}\right)$; $\phi$ is angle of internal friction of roof strata $\left(^{\circ}\right)$; thus:

$$
h=r \cos \alpha=r_{0} e^{\theta \tan \varphi} \cos \alpha
$$

From the geometric equivalence relation:

$$
\alpha=\frac{\pi}{2}-\left[\frac{\pi}{2}-\theta+\left(\frac{\pi}{4}-\frac{\phi}{2}\right)\right]
$$

By substituting Equation (7) into Equation (6):

$$
h=r_{0} e^{\theta \tan \varphi} \cos \alpha=\mathrm{r}_{0} e^{\theta \tan \varphi} \cos \left(\theta+\frac{\varphi}{2}-\frac{\pi}{4}\right)
$$

When $\frac{d h}{d \theta}=0, h$ reaches the maximum, hence:

$$
\frac{d h}{d \theta}=r_{0} e^{\theta \tan \varphi} \cos \left(\theta+\frac{\varphi}{2}-\frac{\pi}{4}\right) \tan \varphi-r_{0} e^{\theta \tan \varphi} \sin \left(\theta+\frac{\varphi}{2}-\frac{\pi}{4}\right)=0
$$

that is:

$$
\tan \varphi=\tan \left(\theta+\frac{\varphi}{2}-\frac{\pi}{4}\right)
$$

Thus;

$$
\theta=\frac{\phi}{2}+\frac{\pi}{4}
$$

As:

$$
r_{0}=\frac{L}{2 \cos \left(\frac{\pi}{4}+\frac{\varphi}{2}\right)}
$$


Hence, the maximum depth of the yield zone is:

$$
h_{\max }=r_{0} e^{\left(\frac{\phi}{2}+\frac{\pi}{4}\right) \tan \phi} \cdot \cos \alpha=\frac{L \cdot \cos \alpha}{2 \cos \left(\frac{\pi}{4}+\frac{\phi}{2}\right)} e^{\left(\frac{\pi}{4}+\frac{\phi}{2}\right) \tan \phi}
$$

According to [23] and the above analysis, for a cover depth of $200 \mathrm{~m}$ (the average cover depth of the case study longwall panels), the stress concentration distribution within the floor strata is shown in Figure 14b. It shows that the floor strata on the gob side are in a destressed state, while the floor strata on the solid coal side are in a stressed state. The NGE is located right within the destressed zone of the floor strata. Therefore, the stress environment for the NGE is improved.

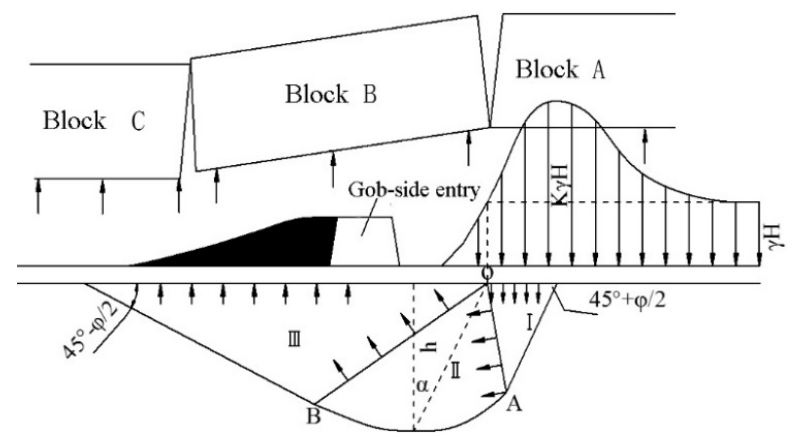

(a)

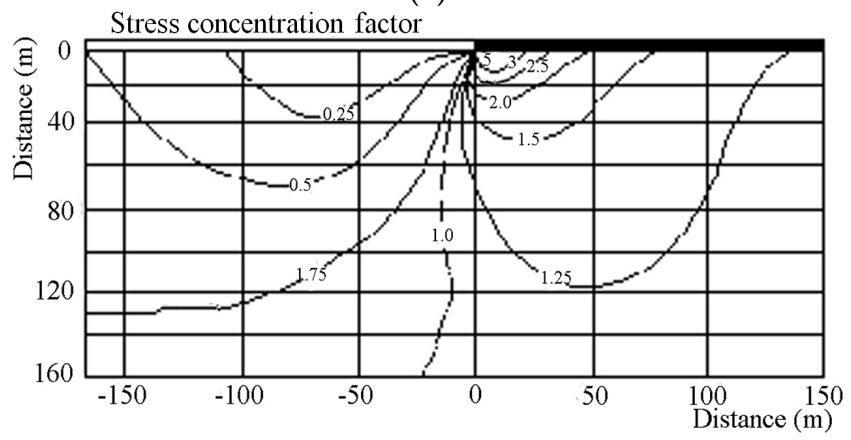

(b)

Figure 14. Stress distribution within floor strata. (a) Slip line field theory [23]; and (b) stress concentration distribution for floor strata.

A structural model developed for the roof strata movement using the NGE approach is shown in Figure 15. The top part of the conventional triangular slender pillar seems to be struck off creating a low-stress interspace for the stress and energy around NGE to dissipate, and the pressure of the masonry beam is transferred to the gob and abutment to the right of the NGE. Thus, the 18111-1 tailgate is only subjected to the weight of caved rock fragments near the gob edge, which is very low. An additional advantage is that the inner stress field discussed by Li [7] (Figure 4) that was caused by the deformed contact, is now located in the solid coal mass on the right of the 18111 maingate rather than next to the gob-side entry.

The horizontal span $L_{b}$ of the Block B [24] is related to the periodic roof weighting interval of the main roof $L_{p}$ and the panel width $L$, which is expressed by:

$$
L_{b}=\frac{2 L_{p}}{17}\left(\sqrt{\left(10 \frac{L_{p}}{L}\right)^{2}+102}-10 \frac{L_{p}}{L}\right)
$$


In conventional LTCC, since a rectangular pillar is left between adjacent panels, the mining system for each panel is isolated. Therefore, before the first periodic weighting, the main roof strata acts like a plate clamped rigidly at four edges, as shown in Figure 16a. After the first periodic weighting, the main roof strata acts like a plate clamped rigidly at three edges with one free edge behind the working face, as shown in Figure 16b. However, for the 18111-1 panel using the NGE, before the first weighting, the edge of the 18111 panel side is free, as shown in Figure 16c. After the first weighting, the main roof strata acts like a plate clamped rigidly at two edges with the other two free edges (one on the 18111 panel side and one behind the working face), as shown in Figure 16d.

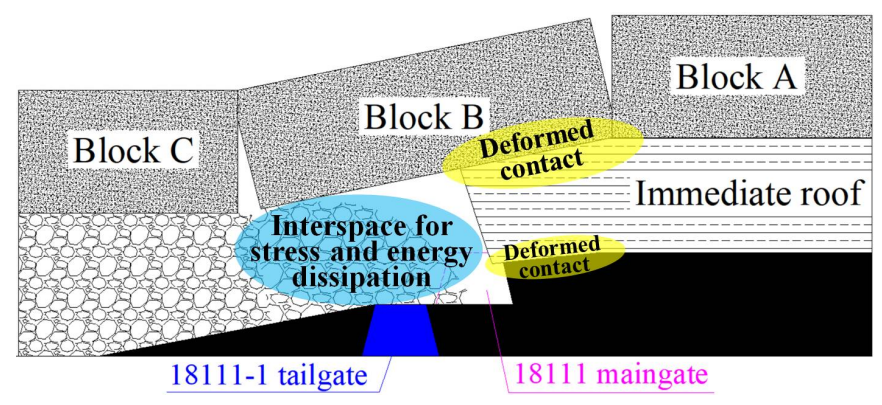

Figure 15. A structural model showing the characteristics of roof strata movements during the extraction of the 18111 panel employing the NGE (after Qian [2] and Tan [4]).

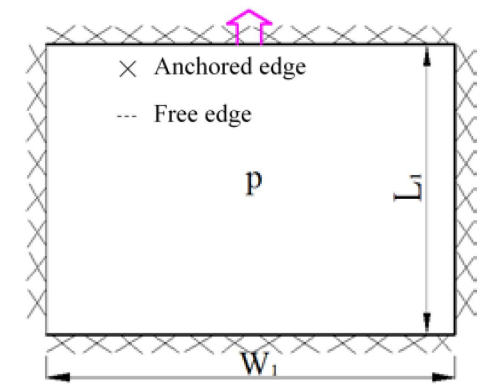

(a)

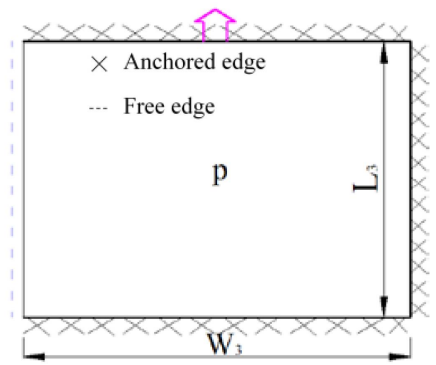

(c)

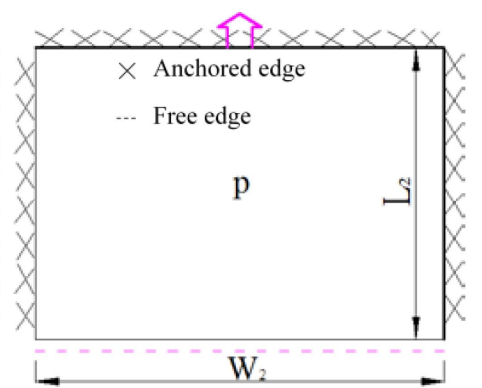

(b)

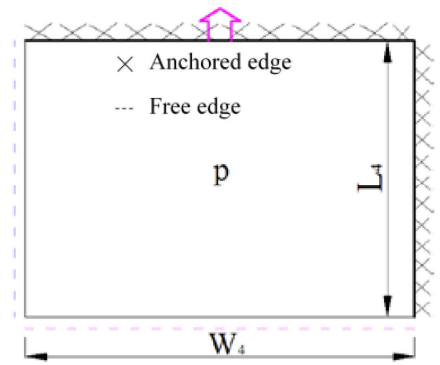

(d)

Figure 16. Roof strata support conditions during the excavation of 18111-1 panel (plan view). (a) Before the first periodic weight; (b) after the first periodic weight; (c) before the first periodic weighting; and (d) after the first periodic weighting.

\section{Numerical Modeling}

A few researchers [8,9] studied the gob-side entry using numerical modeling and gob behavior was involved. Some researchers specifically studied the gob behavior $[18,20,25,26]$, but none considered the influence of the angle of break. Programs used by researchers included such software as PAFEC (Program for Automatic Finite Element Calculations), FLAC (Fast Lagrangian Analysis of Continua), and FLAC ${ }^{3 D}$ (Fast Lagrangian Analysis of Continua in 3 Dimensions). FLAC [27] which has a higher 
solution speed and lower memory requirement is used for two-dimensional plane-strain modeling of the NGE. The built-in double-yield constitutive model in FLAC represents a material in which there may be significant irreversible compaction in addition to shear yielding, such as hydraulically-placed backfill or lightly-cemented granular material [27].

The model grid and assigned materials are shown in Figure 17. The dimensions of the model are $380 \mathrm{~m}$ (length) $\times 75.71 \mathrm{~m}$ (height). At the top of the model, a uniform vertical stress of $162.08 \mathrm{~m} \times$ $0.027 \mathrm{MPa} / \mathrm{m}=4.38 \mathrm{MPa}$ was applied to simulate the overburden weight. An angle of break of $30^{\circ}$ obtained by physical modeling was incorporated. The horizontal sides were roller constrained and the bottom boundary was fixed both horizontally and vertically. Mohr-Coulomb constitutive properties were used for different lithologies and the double-yield model was used to define the gob. Rock mass engineering properties used for numerical modeling are given in Table 1.

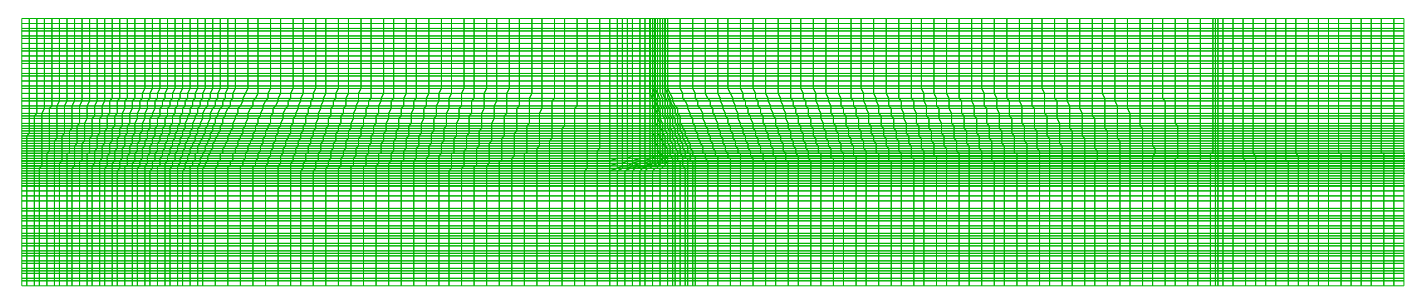

(a)

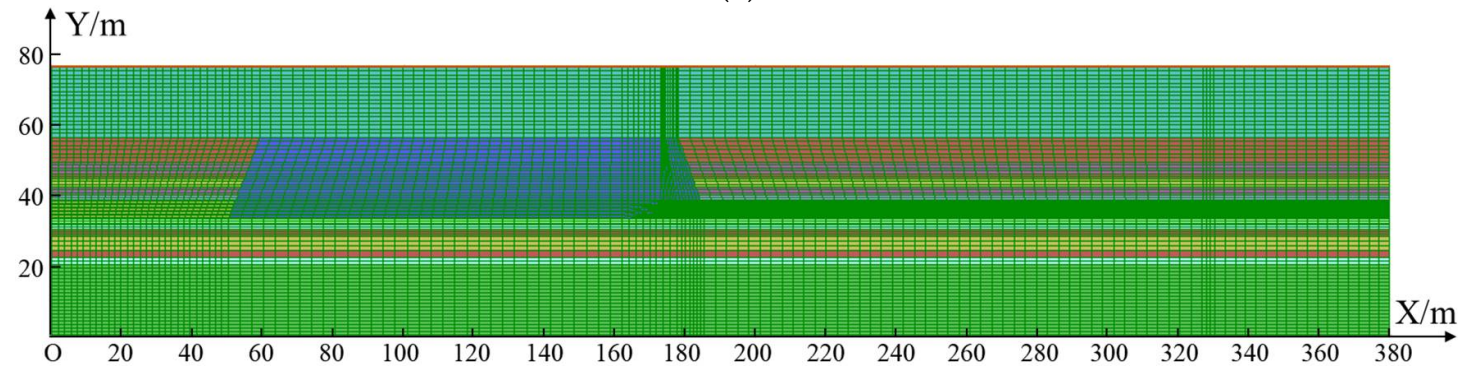

(b)

Figure 17. Model development. (a) Model grid; and (b) assigned model materials (corresponding to the lithology in Table 1).

Table 1. Rock mass mechanical parameters used in the numerical modeling.

\begin{tabular}{|c|c|c|c|c|c|c|c|c|}
\hline Lithology & $\begin{array}{l}\text { Thickness } \\
\text { (m) }\end{array}$ & $\begin{array}{l}\text { Depth } \\
\text { (m) }\end{array}$ & $\begin{array}{l}\text { Density } \\
\left(\mathrm{kg} / \mathrm{m}^{3}\right)\end{array}$ & $\begin{array}{c}\text { Bulk } \\
\text { Modulus } \\
\text { (GPa) }\end{array}$ & $\begin{array}{l}\text { Shear } \\
\text { Modulus } \\
\text { (GPa) }\end{array}$ & $\begin{array}{l}\text { Cohesion } \\
\text { (MPa) }\end{array}$ & $\begin{array}{l}\text { Tensile } \\
\text { Strength } \\
\text { (MPa) }\end{array}$ & $\begin{array}{c}\text { Internal } \\
\text { Friction } \\
\text { Angle (deg) }\end{array}$ \\
\hline Top & 20.0 & 162.1 & 2600 & 7.6 & 5.9 & 1.6 & 0.6 & 28 \\
\hline Silty mudstone & 6.4 & 182.1 & 2550 & 8.2 & 6.5 & 1.7 & 0.7 & 30 \\
\hline Siltstone & 3.7 & 188.5 & 2540 & 10.7 & 7.4 & 2.5 & 0.9 & 32 \\
\hline Silty mudstone & 1.4 & 192.2 & 2550 & 8.2 & 6.5 & 1.7 & 0.7 & 30 \\
\hline \#7 coal seam & 2.3 & 193.6 & 1400 & 1.7 & 1.1 & 0.5 & 0.2 & 18 \\
\hline Siltstone & 2.3 & 195.9 & 2540 & 10.7 & 7.4 & 2.5 & 0.9 & 32 \\
\hline Limestone & 1.8 & 198.2 & 2500 & 9.0 & 7.7 & 2.3 & 0.8 & 31 \\
\hline \#8 coal & 5.0 & 200.0 & 1400 & 1.7 & 1.1 & 0.5 & 0.2 & 18 \\
\hline $\begin{array}{l}\text { Fine grained } \\
\text { sandstone }\end{array}$ & 1.1 & 205.0 & 2550 & 11.5 & 8.5 & 3.0 & 1.0 & 32 \\
\hline Mudstone & 1.4 & 206.1 & 2550 & 6.2 & 4.5 & 1.3 & 0.6 & 27 \\
\hline Coal & 0.3 & 207.5 & 1400 & 1.7 & 1.1 & 0.5 & 0.2 & 18 \\
\hline Silty mudstone & 2.2 & 207.8 & 2550 & 8.2 & 6.5 & 1. 7 & 0.7 & 30 \\
\hline Coal & 4.0 & 210.0 & 1400 & 1.7 & 1.1 & 0.5 & 0.2 & 18 \\
\hline Silty mudstone & 1.8 & 214.0 & 2550 & 8.2 & 6.5 & 1.7 & 0.7 & 30 \\
\hline Mudstone & 2.0 & 215.8 & 2550 & 6.2 & 4.5 & 1.3 & 0.6 & 27 \\
\hline Bottom & 20.0 & 217.8 & 2600 & 7.6 & 5.9 & 1.6 & 0.6 & 28 \\
\hline
\end{tabular}


A double-yield model was used to simulate the compaction of the gob material in FLAC. Pappas and Mark [21] studied the behavior of simulated longwall gob material using laboratory tests and concluded that Salamon's equation closely follows the laboratory results. Therefore, the gob model calibrations were done [28] using equivalent gob elements that follow Salamon's model (Equation (15)):

$$
\sigma=\frac{E_{0} \varepsilon}{1-\varepsilon / \varepsilon_{m}}
$$

where $\sigma$ is the uniaxial stress applied to the material (MPa); $\varepsilon$ is the strain occurring under the applied stress $\mathrm{m} / \mathrm{m} ; \varepsilon_{m}$ is the maximum possible strain of the bulked rock material $\mathrm{m} / \mathrm{m}$ and $\varepsilon_{m}=(b-1) / b$; $b$ is the bulking factor and $b=\left(H_{c}+m\right) / H_{c} ; H_{c}$ is the height of roof caving zone, $(\mathrm{m})$; $E_{0}$ is the initial tangent modulus (MPa), and $E_{0}=10.39 \sigma_{c}{ }^{1.042} / b^{7.7}(\mathrm{MPa})$; and $\sigma_{c}$ is the in situ vertical stress, (MPa).

For the 18111 panel, the mining height $(\mathrm{m})$ is $5 \mathrm{~m}$, and the average height of the caved zone is about $17.9 \mathrm{~m}$ above the coal seam depending on observation of the gob gas wells. Hence, the bulking factor was calculated as 1.28. According to the Equation (15), the maximum strain of the gob and the initial gob modulus was calculated as 0.22 and 7.26 MPa, respectively. Cap pressures for the double-yield model are shown in Table 2 and are expressed by:

$$
\sigma=\frac{7.26 \varepsilon}{1-4.58 \varepsilon}
$$

Table 2. Cap pressures for the double-yield model.

\begin{tabular}{cccc}
\hline Strain $(\mathbf{m} / \mathbf{m})$ & Stress $(\mathbf{M P a})$ & Strain $(\mathbf{m} / \mathbf{m})$ & Stress $(\mathbf{M P a})$ \\
\hline 0.00 & 0 & 0.11 & 1.61 \\
0.01 & 0.08 & 0.12 & 1.93 \\
0.02 & 0.16 & 0.13 & 2.33 \\
0.03 & 0.25 & 0.14 & 2.83 \\
0.04 & 0.36 & 0.15 & 3.48 \\
0.05 & 0.47 & 0.16 & 4.35 \\
0.06 & 0.60 & 0.17 & 5.57 \\
0.07 & 0.75 & 0.18 & 7.44 \\
0.08 & 0.92 & 0.19 & 10.63 \\
0.09 & 1.11 & 0.20 & 17.28 \\
0.10 & 1.34 & 0.21 & 39.90 \\
\hline
\end{tabular}

A test was carried out to obtain a set of reasonable parameters of the double-yield constitutive gob model. A simple model with dimensions $1 \mathrm{~m} \times 2 \mathrm{~m}$ was constructed. Loading was simulated by applying a velocity on the top surface with fixed sides along the $\mathrm{X}$ axis, and fixed boundaries both in the $\mathrm{X}$ and $\mathrm{Y}$ directions. The input parameters were fitted by an iterative change in the bulk and shear modulus, the angle of dilation, the angle of friction, and the density of the gob material. The volumetric strain, vertical stress contours, and FLAC numerical stress-strain curves are shown in Figure 18 to obtain the fitted parameters. The final properties are given in Table 3. A comparison between the numerically-obtained strain-hardening curve and Salamon's theoretical curve is shown in Figure 19. The interface parameters used in modeling were: normal stiffness of $1.0 \times 10^{9} \mathrm{~Pa}$; shear stiffness of $1.0 \times 10^{9} \mathrm{~Pa}$; cohesion of $1 \times 10^{5} \mathrm{~Pa}$; angle of internal friction of $20^{\circ}$; and the shear bond is 100 times the tensile bond [27].

Table 3. Parameters for gob material.

\begin{tabular}{ccccc}
\hline $\begin{array}{c}\text { Density } \\
\left(\mathbf{k g} / \mathbf{m}^{\mathbf{3}}\right)\end{array}$ & $\begin{array}{c}\text { Bulk Modulus } \\
(\mathbf{M P a})\end{array}$ & $\begin{array}{c}\text { Shear Modulus } \\
\mathbf{( M P a )}\end{array}$ & $\begin{array}{c}\text { Angle of Dilation } \\
\left({ }^{\circ}\right)\end{array}$ & $\begin{array}{c}\text { Angle of Internal } \\
\text { Friction }\left(^{\circ}\right)\end{array}$ \\
\hline 1700 & 4000 & 4200 & 6.5 & 42 \\
\hline
\end{tabular}




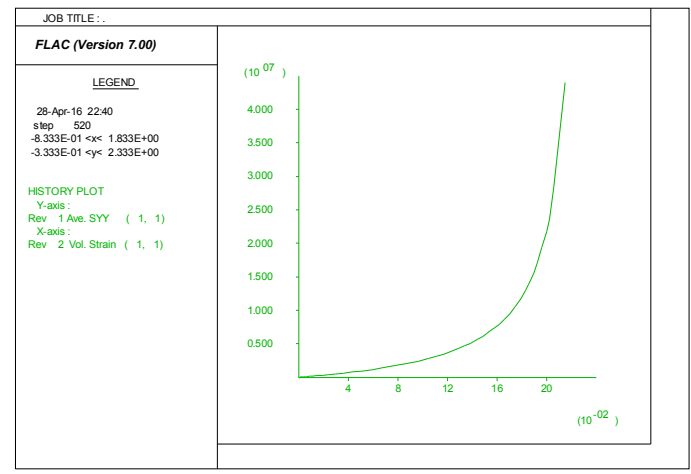

(a)

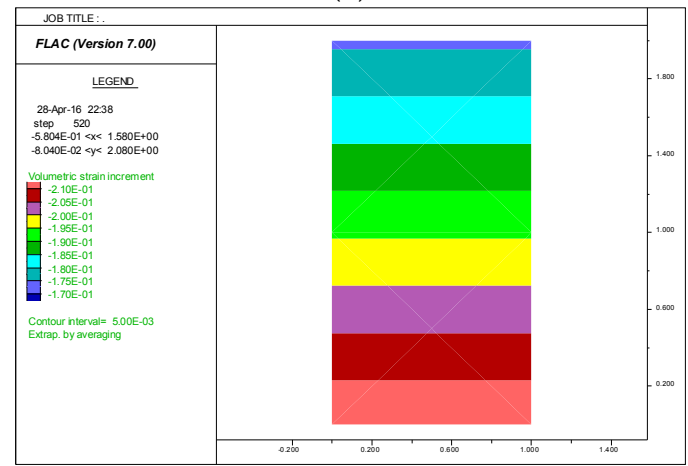

(b)

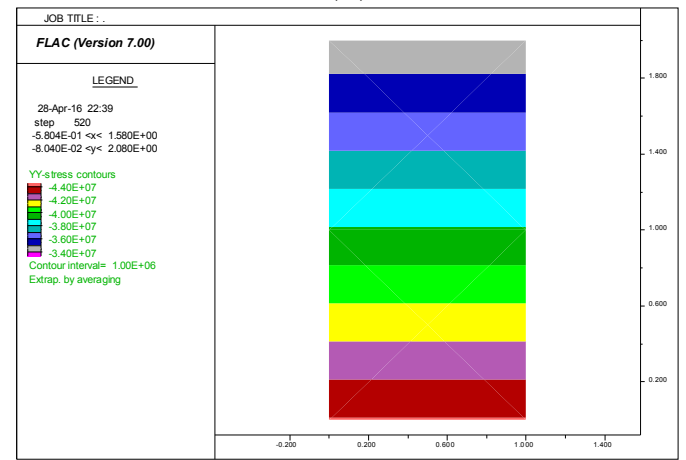

(c)

Figure 18. Strain and stress contours using the fitted parameters. (a) Strain-hardening curve; (b) volumetric strain; and (c) vertical stress.

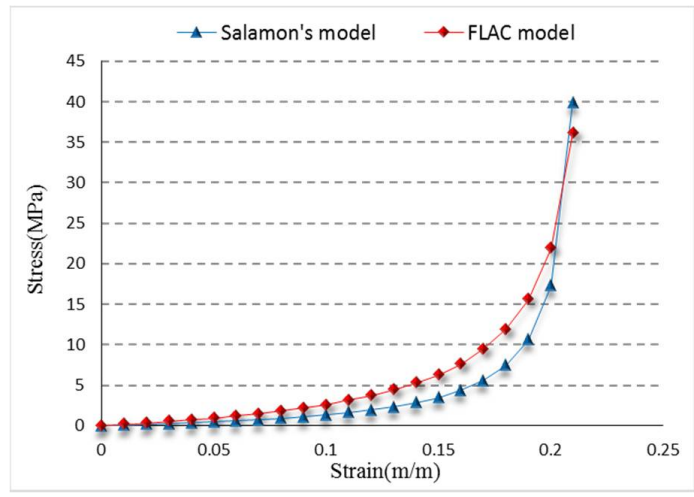

Figure 19. A comparison between the numerically-obtained stress-strain curve and Salamon's theoretical curve. 


\section{Numerical Modeling Results and Discussion}

Figure 20 shows vertical stress distribution after excavation of the 18111 panel. The distance between the gob edge and the location where pre-mining stress is reached in the gob is about $51 \mathrm{~m}$. This agrees with the rule of thumb proposed by Wilson [29] that the pre-mining stress is achieved $0.2-0.3$ times the panel overburden depth. It is also observed that the elevating section is located in the destressed zone. Therefore, the gateroads located here would suffer lower ground pressure and the ground control problems would be, consequently, minimal. According to records of several panels in the Zhenchengdi coal mine, dynamic disasters, such as rockbursts or coal and gas outbursts, never occurred. In addition, Figure 20b indicates that the abutment pressure on the side of the elevating section is smaller and the gob pressure increases faster. This means that the load borne by the gob is larger, especially for the elevating section.

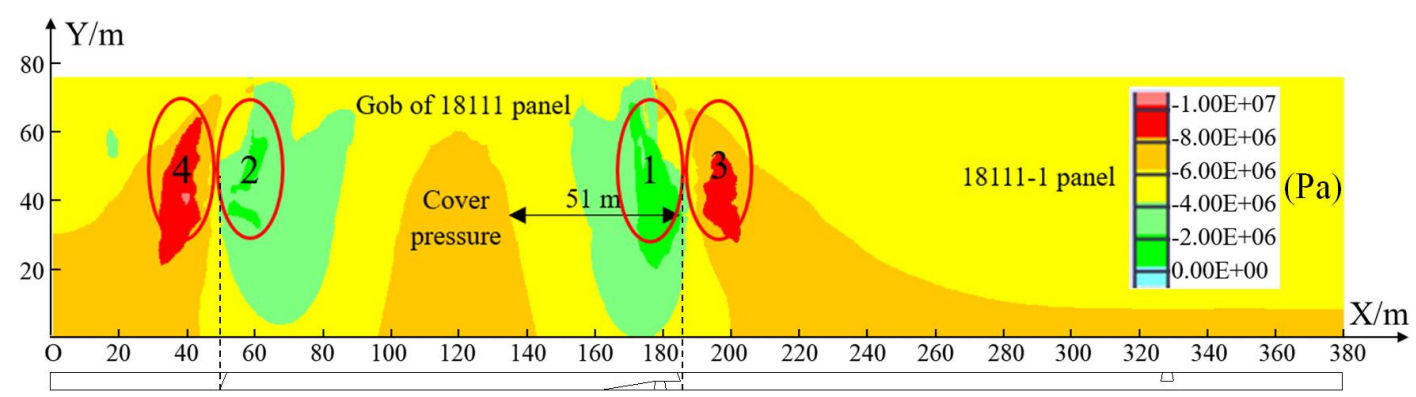

(a)

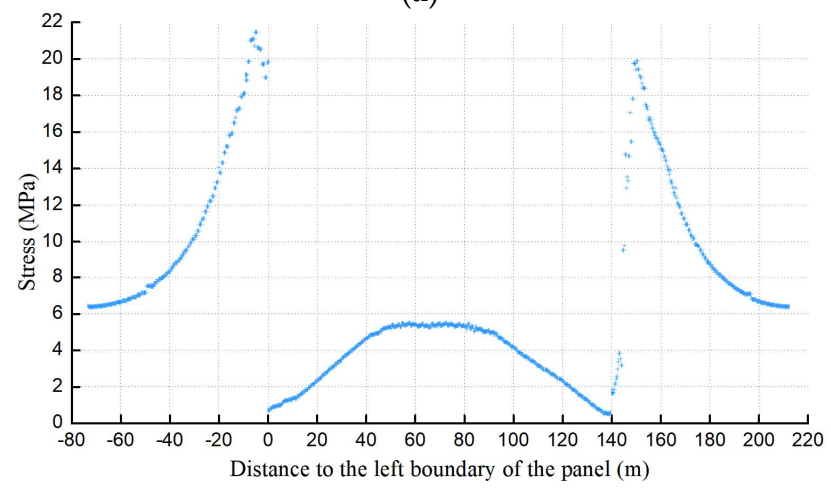

(b)

Figure 20. Vertical stress distribution after excavation of the 18111 panel. (a) Stress contour; and (b) stress distribution along the floor.

Detailed analyses included the stress values in the top zones of the elevating section from 1 to 21 along the top of the elevating section (Figure 21), with results shown in Figure 22. As seen, the vertical stress at the gob edge is less than $0.5 \mathrm{MPa}$, which is far less than the in situ vertical stress of $200 \mathrm{~m} \times 0.027 \mathrm{MPa} / \mathrm{m}=5.4 \mathrm{MPa}$. Even on the top of the gob-side entry of the 18111-1 panel, i.e., monitored element " 6 " (Figure 22), the vertical stress is only about $0.5 \mathrm{MPa}$ and the stress concentration factor is less than 0.1 . Thus, the stress environment for the gob-side entry is significantly improved.

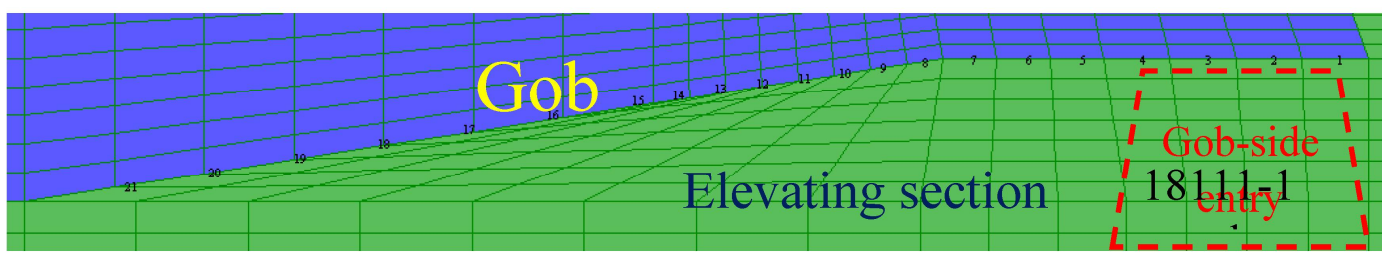

Figure 21. Monitored zones. 


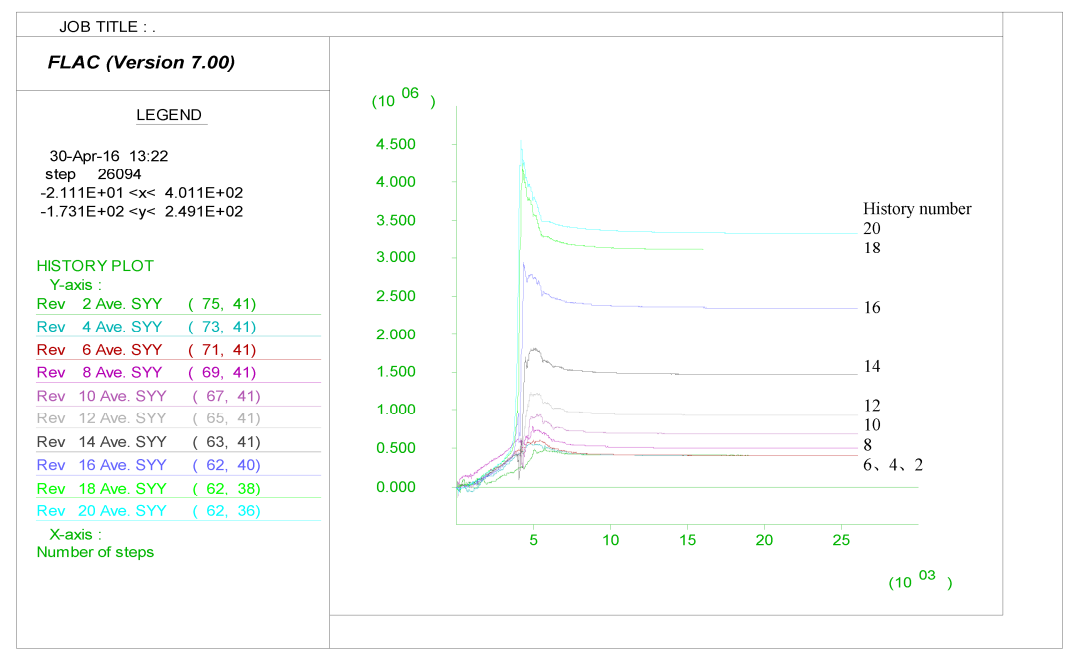

Figure 22. Vertical stress in elements at the gob edge of the 18111 panel.

Readers may also note that the gob pressure distributions of physical modeling and numerical modeling are different. This is because that the roof subsidence does not reach the surface in physical modeling, and not all the overburden weight is sustained by the gob at the center of the panel, rather, the pressure is transferred to the abutments. This is also demonstrated by the fact that the abutment pressure in physical modeling is larger than that in numerical modeling.

\section{Field Testing and Field Observation}

\subsection{Support Design for the New Gob-Side Entry}

The layout of the gob-side entry determines its unique support system. For the NGE, experience from the multi-slicing longwall mining technology was used to decide on the support system.

During the extraction of the 18111 panel, \#10 steel wire mesh was used along the elevating section of the 18111 panel (about 8-10 m wide). The wire mesh allows the development of the artificial roof for the gob-side entry of 18111-1 panel. Over six months after the extraction of the 18111 panel, the gob-side entry was excavated. An ELMB-75C machine (Hang Tian Chen Guang Co., Ltd., Nanjing, China) was employed for tunneling along with SGW-40T (Hua Yun An Te Co., Ltd., Beijing, China) type conveyor for transportation of coal. Each cut width was $0.8 \mathrm{~m}$, and the cutting height was controlled to avoid damaging the roof steel wire mesh. Trapezoidal steel yieldable sets made of \#11 I-shaped mine steel spaced at $800 \mathrm{~mm}$ were used for roadway support. The leg height was $2700 \mathrm{~mm}$, and the top beam was $3100 \mathrm{~mm}$ long. Four laggings were used on the top pf the steel sets, and three laggings for the coal ribs. Figure 23 presents the detailed design.

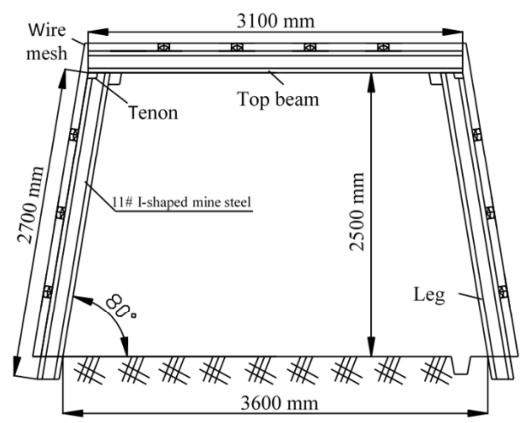

(a)

Figure 23. Cont. 


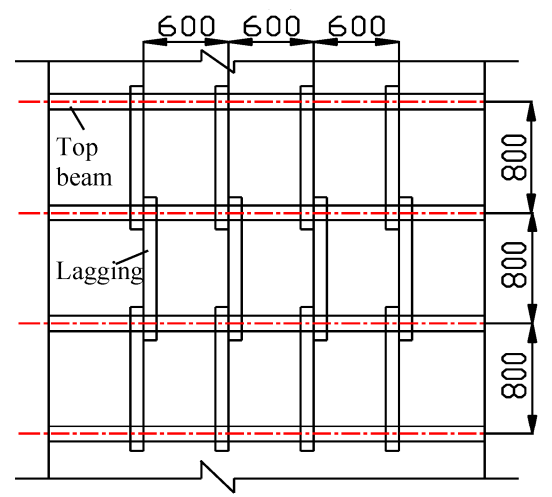

(b)

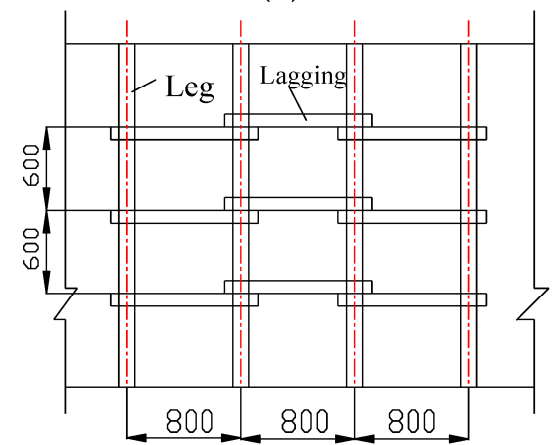

(c)

Figure 23. Support design for 18111-1 tailgate. (a) Cross-section view; (b) top view; (c) longitudinal view.

The support system should have capacity greater than the following equation to ensure stability:

$$
P_{T}=H_{I} \gamma_{I}
$$

where $H_{I}$ is the height of the immediate roof, and $\gamma_{I}$ is the unit weight of the immediate roof, $0.027 \mathrm{MN} / \mathrm{m}^{3}$ (note that immediate roof here is a general definition which refers to the one or several roof strata that will become fragmented rocks within the caved zone).

From an engineering background we know that $H_{I}=17.9 \mathrm{~m}$, thus, $P_{T}=0.48 \mathrm{MPa}$, which agrees very well with numerical modeling data that the vertical stress is only about $0.5 \mathrm{MPa}$ and the stress concentration factor is less than 0.1. The numerical global model is, therefore, validated as well. A safety factor of 3 is used and, therefore, $P_{T}=0.15$ is required.

\subsection{Field Monitoring Studies}

\subsubsection{Support Resistance of Shields}

Along the 18111-1 working face, the gob-side entry side to the maingate side, No. 5, 30, 59, and 76 shields located right over the elevating section were installed with two monitoring recorders for each shield. The number of support cycles varied from $6-8$ each day with $0.6 \mathrm{~m}$ of face advance for each cycle. Due to large quantity of data, only 292 cycles of data were analyzed. Initial setting pressure $P_{0}$, final pressure $P_{m}$, time-weighted average resistance (TWAR) $P_{t}$ [30], and $P_{m}{ }^{\prime}$ vs. the number of shield supporting cycles together with the amount of face advance are plotted in Figure 24, as well as an illustration of the locations of the monitored shields and:

$$
p_{t}=\frac{\frac{1}{2}\left(p_{0}+p_{1}\right) t_{1}+\frac{1}{2}\left(p_{1}+p_{2}\right) t_{2}+\cdots+\frac{1}{2}\left(p_{\mathrm{n}-1}+p_{\mathrm{n}}\right) t_{\mathrm{n}}}{t_{1}+t_{2}+\cdots+t_{\mathrm{n}}}
$$




$$
p_{m}=\bar{p}_{m}+\sigma_{p_{m}}
$$

where $\bar{p}_{m}$ is the average TWAR, $\sigma_{p m}$ is the mean square error, and $P_{1}, P_{2}, \ldots, P_{n}$ is the support resistance during the corresponding period of $t_{1}, t_{2}, \ldots, t_{n}$, as shown in Figure 25.

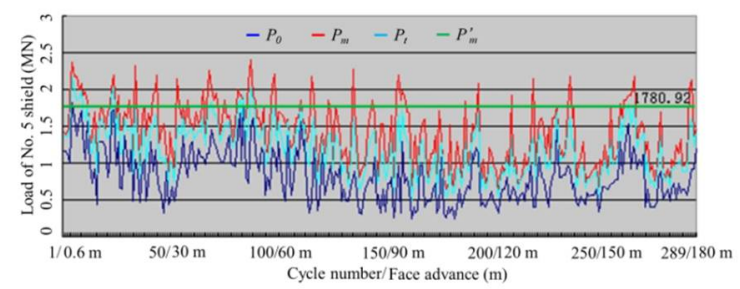

(a)

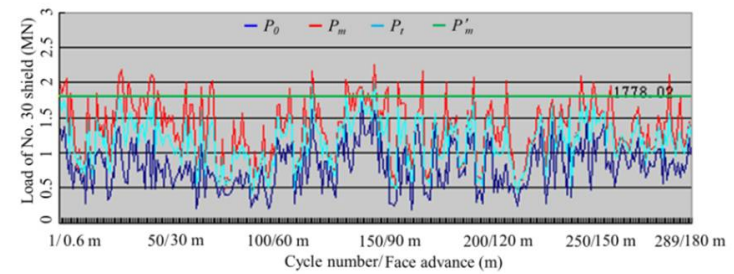

(b)

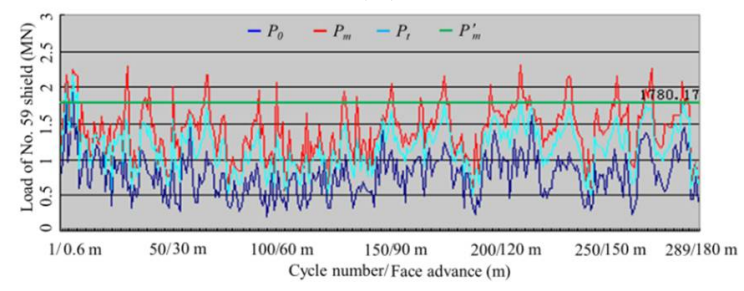

(c)

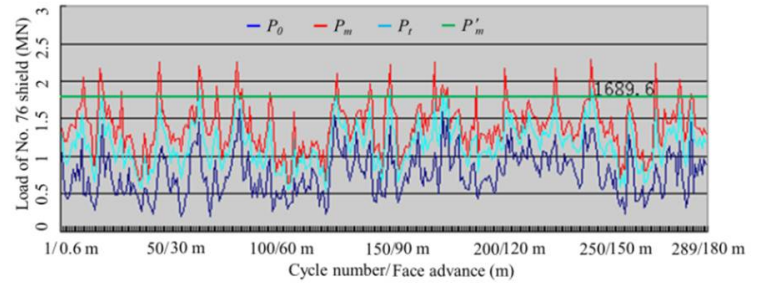

(d)

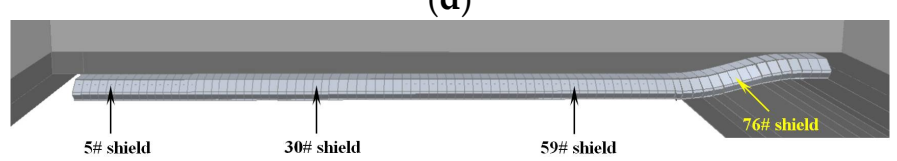

(e)

Figure 24. Shield pressure data and location of the monitored shields. (a) No. 5 shield; (b) no. 30 shield; (c) no. 59 shield; (d) no. 76 shield; and (e) location of the monitored shields.

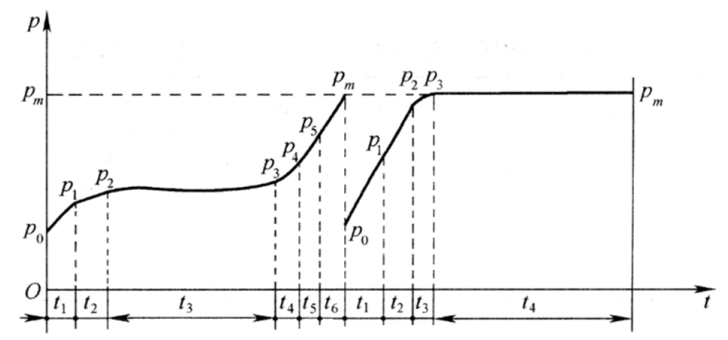

Figure 25. Typical pressure changes in a shield support cycle. 
Taking pressures larger than $p_{m}{ }^{\prime}$ as the signs of periodic roof weighting, there was a periodic roof weighting every 15-20 cycles. Therefore, the periodic roof weighting interval varies from 9 to $12 \mathrm{~m}$, and according to Equation (14):

$$
\begin{aligned}
& L_{b \min }=\frac{2 \times 9}{17}\left(\sqrt{\left(10 \times \frac{9}{130}\right)^{2}+102}-10 \times \frac{9}{130}\right)=9.99 \mathrm{~m} \\
& L_{b \max }=\frac{2 \times 9}{17}\left(\sqrt{\left(10 \times \frac{9}{130}\right)^{2}+102}-10 \times \frac{9}{130}\right)=13.01 \mathrm{~m}
\end{aligned}
$$

Thus, the width of Block B was calculated as 10 to $13 \mathrm{~m}$.

\subsubsection{Pressure Distribution in the Elevating Section}

The gradually elevating section may be analyzed as a triangular section, as shown in Figure 26. The length of the elevating section is about $15 \mathrm{~m}$, height of the entry is $2.5 \mathrm{~m}$, thus, the inclination of the elevating section is $\arctan (2.5 / 15)=9.46^{\circ}$. Therefore, the mining height $M_{h}$ of the elevating section is estimated as:

$$
M_{h}=5-l \times \tan 9.46^{\circ}(l \leq 15 \mathrm{~m})
$$

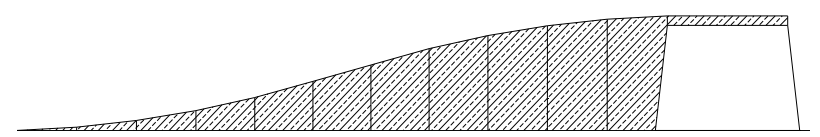

(a)

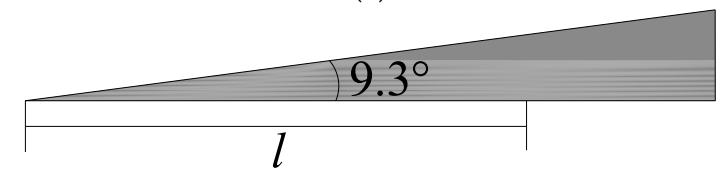

(b)

Figure 26. Simplified elevating section. (a) Actual configuration; and (b) idealized configuration.

By substituting Equation (20) into Equation (3), the vertical stress over this section is obtained and is given as follows:

$$
\sigma_{X l}=\frac{10.39 \sigma_{c}^{1.042}(b-1)\left(S_{x}+\frac{0.4\left(5-l \tan 9.46^{\circ}\right)}{c_{3} h+c_{4}}-0.05\left(5-l \tan 9.46^{\circ}\right)^{1.2}\right)}{\left(\left(5-l \tan 9.46^{\circ}\right) b^{8.7}-0.05\left(5-l \tan 9.46^{\circ}\right)^{1.2} b^{7.7}\right)-b^{8.7}\left(S_{x}+\frac{0.4\left(5-l \tan 9.46^{\circ}\right)}{c_{3} h+c_{4}}-0.05\left(5-l \tan 9.46^{\circ}\right)^{1.2}\right)}
$$

where $\sigma_{t}$ is the compressive strength (MPa); $\mathrm{b}$ is the bulking factor of the caved roof; $S_{x}$ is the subsidence of surface at distance $x,(\mathrm{~m}) ; x$ is the horizontal distance from the origin, $(\mathrm{m})$, which is located at the center of the subsidence profile; and $c_{3}$ and $c_{4}$ are the coefficients depending on lithology and $l$ is the distance between a certain point along the bottom of the elevating section to the vertex, $(\mathrm{m})$.

Since subsidence data are currently not available, it is proposed that this equation be validated in future papers.

\subsubsection{Pressure and Convergence in Gateroads of the 18111-1 Panel}

Pressure and convergence monitoring were carried out in both gateroads, that is, 18111-1 tailgate (the gob-side entry) and 18111-1 maingate. Immediately after the steel sets were installed on drivage, automated recording load cells were inserted on the top of the steel sets ahead of the face within the gateroads to collect pressure data. The convergences of the gateroads were monitored, as shown in Figure 27. The locations of the measurement points were selected in the middle of the two adjacent steel 
sets where the roof was clearly exposed and ready to be marked. Permanent pins were installed in the roof, floor, pillar rib, and longwall panel rib for each measurement station, respectively. Convergences were measured by a flexible tape. Differences of " $\mathrm{AB}$ " and " $\mathrm{CD}$ " with respect to their initial values at a certain location represent rib-to-rib convergence and roof-to-floor convergence, respectively. The data obtained are plotted in Figures 28 and 29.

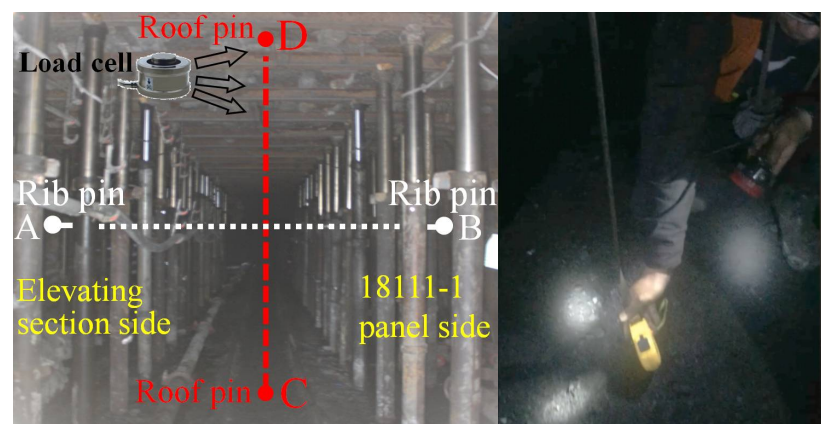

Figure 27. Schematic of load cell locations and the cross monitoring method.

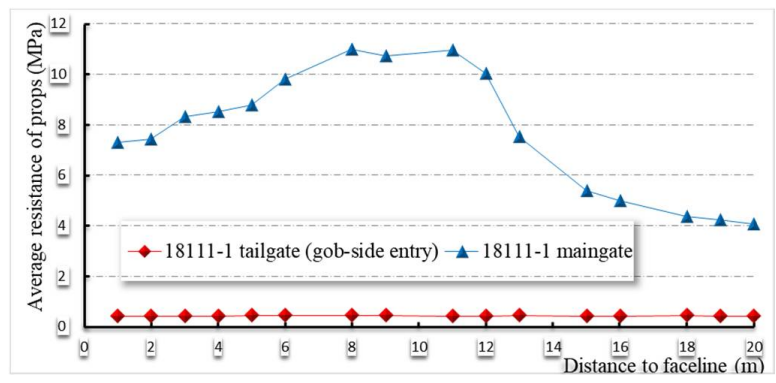

Figure 28. Roof stress data in the gateroads of the 18111-1 panel.

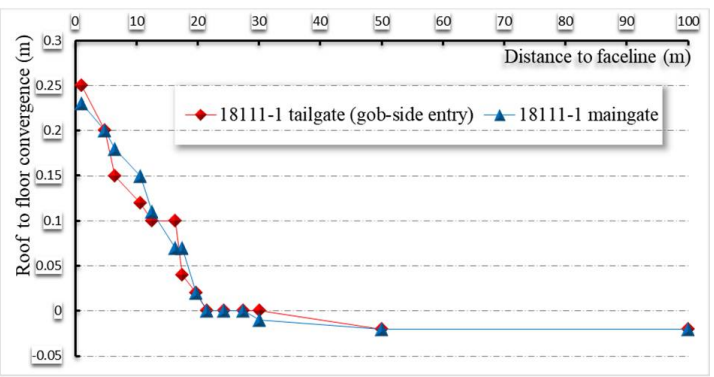

(a)

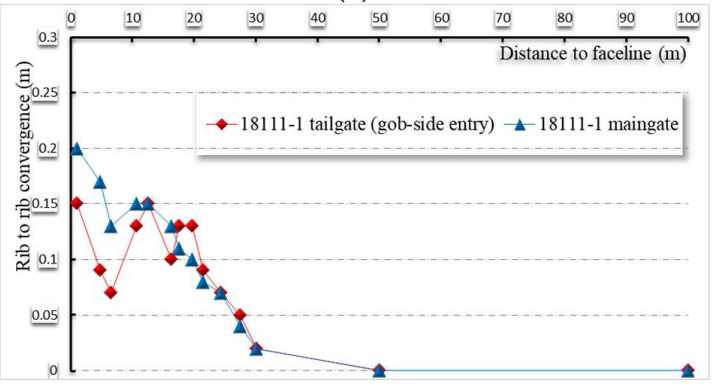

(b)

Figure 29. Convergence in gateroads of the 18111-1 panel. (a) Roof-to-floor convergence in the gateroads of the 18111-1 panel; and (b) rib-to-rib convergence in the gateroads of the 18111-1 panel. 
The support load in the 18111-1 tailgate (gob-side entry) is much lower than that in the 18111-1 maingate and less than the pre-mining stress. This corroborates that the gob-side entry employing the NGE is located within the destressed zone. Steel sets were spaced at $800 \mathrm{~mm}$ along the longitudinal direction of the entry, hence, $400 \mathrm{~mm}$ of the roof on each side is carried by one set, and the roof is $3.1 \mathrm{~m}$ long, thus, the weight carried by one set is $3.1 \times 0.8 \times 1.79 \times 0.027=0.12 \mathrm{MN}$. As the flange width of \#11 I-shaped steel is $90 \mathrm{~mm}$, it is assumed that all the weight of the caved rock fragments of the immediate roof acts on the top beam, thus, the average stress on the top of the beam is $0.12 /(0.09 \times 3.1)=0.43 \mathrm{MPa}$, which also agrees very well with the numerical modeling results. The average value is lower than $0.43 \mathrm{MPa}$. It is believed that this is due to the influence of the angle of break. This is similar to multi-slice longwall mining where the panel gateroads in the lower seam are located directly underneath the gob of the immediate super-adjacent seam. Thus, the gateroads in the lower slice are located within the destressed zone of the super-adjacent panel [30]. In addition, the data show that the roof pressure is maintained at about $0.42 \mathrm{MPa}$ without much fluctuation. This proves that the gob-side entry is independent of the side and front abutment pressure, which validates the theoretical analysis and numerical modeling. Therefore, the NGE has significant advantages from a ground control point of view.

Convergence for the two gateroads of 18111-1 panel shows that roof-to-floor convergence is similar and is small. Rib-to-rib convergence indicates that the gob-side entry converged less laterally than the non-gob-side entry which means the lateral pressure acting on the gob-side entry is not large either. In fact, according to engineering experience, the most roof to floor convergence result from the deformation of the pseudo-roof. The value of the deformation depends on the meshing quality and support design of the support system, such as the interval of adjacent steel sets, the density of lagging, etc. Nearly no convergences were observed in the gob side entry of the 22204 panel at this coal mine. Therefore, it demonstrates that the overall stress environment in the gob-side entry employing the NGE is improved. Thus, ground control problems, such as roof falls, bumps, and outbursts, are minimized and operation costs should be lower. Tangshan, Huafeng, and Dayuan coal mines, among others, are using the technology for deep inclined thick coal seams [31-33].

\section{Pros and Cons of the NGE}

The two adjacent panels must be extracted sequentially. As the gob-side entry of the panel is driven directly under the artificial roof or pseudo-roof of the gob edge of the panel, the development of the gob-side entry should be done at least six months (preferably one year) after extraction of the 18111 panel. This time is required to allow the caved and fractured roof strata to compact [30]. This point must be considered when a coal mine plans to use the NGE approach. Fortunately, this case study coal mine uses a two-wing longwall system as shown in Figure 30. The panels are mined in numbered order. For instance, \#1 panel is first mined, then \#2 panel is mined. Thus, it has been over six months after the \#1 panel is mined when the \#3 panel starts to be mined. If a coal mine uses one-wing system, then mining every other panel can be adopted for NGE.

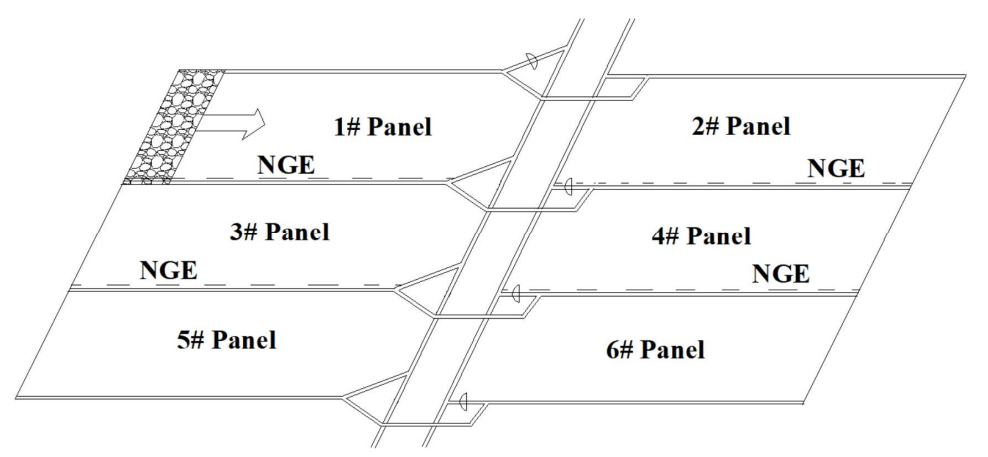

Figure 30. Two-wing longwall system for NGE. 
Coal mines currently using the NGE are all single-entry or two-entry systems. NGE is in use only in China or Russia. This practice may not meet the statutory requirements in many countries around the world. Therefore, additional research should be done to assess the performance of three-, four-, and more-entry panel systems.

Leakage of air from the NGE into the gob is another area of concern. Therefore, the NGE is preferably used for coal seams with low methane content and gob water amount. For the case study coal mine, as the coal seam averages about $5 \mathrm{~m}$, the gob-side entry is totally connected to the gob. By grouting slime water into the gob from the 18111 maingate to the gob edge during extraction of the 18111 panel, the degree of consolidation is increased so that the air leakage meets the ventilation requirement [15]. In addition, grouting slime reduces the spontaneous heating of loose coal in the gob area which means that the prevention and extinguishing of a fire caused by residual loose coal are also rather good. Other proper measures, such as pre-drainage of gas through gob wells or cross-measure drill holes, can also be adopted to control the leakage. Employing an outer offset configuration of the NGE with a slender pillar in between or leaving a coal sheet between the two adjacent panels is shown in Figure 31, then it can be applied for coal seams with a higher gas content.

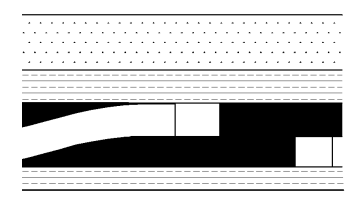

(a)

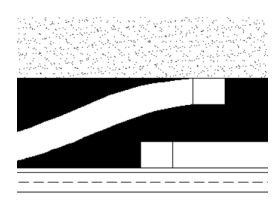

(b)

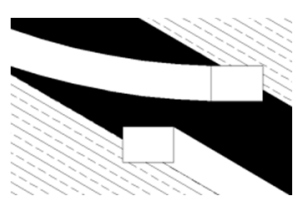

(c)

Figure 31. The NGE for highly-gassy coal seams. (a) with a coal pillar left in between; (b) with a coal sheet left in between; (c) situation (b) in an inclined coal seam.

\section{Concluding Remarks}

This paper has presented a novel design approach to gob-side entry which is relatively easy. In this approach, determining the size of the slender pillar for the gob-side entry is avoided and no artificial wall needs to be constructed. Development entries on either end of the panel employing the NGE approach are located at different vertical levels. The gob-side entry is located at the gob edge and is offset horizontally with respect to the previous mined-out panel. The basic mining principle is similar to multi-slice longwall mining which has been improved using the NGE.

We carried out the theoretical analysis, which shows that the gob-side entry in this approach is located within the most destressed zone in the entire panel system. It is almost in a stress-free state, which avoids dynamic disasters such as coal bumps and coal outbursts. Therefore, the support and maintenance requirements for the gob-side entry are small. The unique geometry also creates a smaller side abutment pressure for the adjacent active panel.

Numerical modeling incorporating the angle of break was carried out. The double-yield model for the gob was calibrated using a simple model by fitting gob strain-hardening behavior with Salamon's theoretical model. Pre-mining stress in the gob is achieved about $51 \mathrm{~m}$ away from the gob edge. Side abutment pressure within the solid coal close to the gob-side entry is smaller than the other side of the gob. The stress concentration factor for the roof on the gob-side entry is less than 0.1. The stress around the gob edge near the gob-side entry is relatively low compared with the other side of the gob of the 18111 panel. The destressing effect of the NGE is evident. Numerical modeling results corroborate the theoretical analyses.

We carried out field testing and field observations. Support design for the NGE is also presented. In summary, the theoretical analysis, numerical modeling, and field observations are consistent and validate the scientific foundation of the new technology. 
Author Contributions: Conceptualization: G.F. and P.W.; methodology: G.F., P.W. and Y.P.C.; investigation: P.W.; writing-original draft preparation: G.F. and P.W.; and writing—review and editing, Y.P.C.

Funding: This research was funded by the National Natural Science Foundation of China, Excellent Young Scientists, grant number 51422404 and the NSFC-Shanxi Joint Fund for Coal-Based Low-Carbon Technology, grant number U1710258.

Acknowledgments: The authors would like to thank Zhengchengdi Colliery for cooperation during the field measurements and monitoring.

Conflicts of Interest: The authors declare no conflict of interest.

\section{References}

1. Nazimko, V.V. Pillarless longwall mining for multiple seams. In Proceedings of the 13th International Conference on Ground Control in Mining, Morgantown, WV, USA, 2-4 August 1994; pp. 239-245.

2. Qian, M.G.; Shi, P.W.; Xu, J.L. Ground Pressure and Strata Control; China University of Mining and Technology Press: Xuzhou, China, 2010.

3. Yan, S.; Bai, J.B.; Wang, X.Y.; Huo, L.J. An innovative approach for gateroad layout in highly gassy longwall top coal caving. Int. J. Rock Mech. Min. Sci. 2013, 59, 33-41. [CrossRef]

4. Tan, Y.L.; Yu, F.H.; Ning, J.G.; Zhao, T.B. Design and construction of entry retaining wall along a gob side under hard roof stratum. Int. J. Rock Mech. Min. Sci. 2015, 77, 115-121. [CrossRef]

5. Suchowerska, A.M.; Merifield, R.S.; Carter, J.P. Vertical stress changes in multi-seam mining under supercritical longwall panels. Int. J. Rock Mech. Min. Sci. 2013, 61, 306-320. [CrossRef]

6. Li, H.M.; Peng, S.S.; Li, H.G.; Xu, Y.X.; Yuan, R.F.; Yue, S.S.; Li, K. Trial of small gateroad pillar in top coal caving longwall mining of large mining height. Int. J. Min. Sci. Technol. 2016, 26, 139-147. [CrossRef]

7. Li, L.; Bai, J.B.; Wang, X.Y. Rational position and control technique of roadway driving along nextgoaf in fully mechanized top coal caving face. J. China Coal Soc. 2012, 37, 1564-1569.

8. Zhang, Z.Z.; Bai, J.B.; Chen, Y.; Yan, S. An innovative approach for gob-side entry retaining in highly gassy fully-mechanized longwall top-coal caving. Int. J. Rock Mech. Min. Sci. 2015, 80, 1-11. [CrossRef]

9. Yang, H.Y.; Cao, S.G.; Li, Y.; Sun, C.M.; Guo, P. Soft Roof Failure Mechanism and Supporting Method for Gob-Side Entry Retaining. Minerals 2015, 5, 707-722. [CrossRef]

10. Zhang, D.S.; Wang, H.S.; Ma, L.Q. Two-step gob-side entry driving technology of pre-build artificialside substitute for narrow coal pillar. J. China Coal Soc. 2010, 35, 1589-1593.

11. Zhang, D.S.; Ma, L.Q.; Feng, G.M.; Miao, X.X. The technique of gob-side entry retaining with entry-in packing on its original position in fully-mechanized coalface with top-coal caving. Chin J. Rock Mech. Eng. 2005, 24, 1164-1168.

12. Zhang, N.; Han, C.L.; Kan, J.G.; Zhang, X.G. Theory and practice of surrounding rock control for pillarless gob-side entry retaining. J. China Coal Soc. 2014, 39, 1635-1641.

13. Shabanimashcool, M.; Li, C.C. Numerical modeling of longwall mining and stability analysis of the gates in a coal mine. Int. J. Rock Mech. Min. Sci. 2012, 51, 24-34. [CrossRef]

14. Zhao, J.L. Whole Seam Longwall Mining with Split-Level Gateroads (LMSG) in Thick Coal Seams. China Patent ZL98100544.6, 2004.

15. Fan, X.M.; Zhao, J.L.; Wang, Y.B.; Wang, Z.Q. Whole Seam Longwall Mining with Split-Level Gateroads and Its Application in Xishan Coal Mine Area; China Coal Industry Publishing House: Beijing, China, 2013.

16. Wang, X.P. Discuss and practice of elaborate mining technology in Zhenchengdi mine. Coal Sci. Technol. 2011, 39, 9-11.

17. Niu, W.F. Prospect of roadway layout under conditions of thick coal seam with large dip angle. Sci. Technol. Inf. 2012, 11, 109-110.

18. Yavuz, H. An Estimation Method for Cover Pressure Re-Establishment Distance and Pressure Distribution in the Gob of Longwall Coal Mines. Int. J. Rock Mech. Min. Sci. 2004, 41, 193-205. [CrossRef]

19. Brady, B.H.; Brown, E.T. Rock Mechanics: For Underground Mining, 3rd ed.; Springer: Dordrecht, The Netherlands, 2006.

20. Esterhuizen, G.S.; Karacan, C.Ö. A methodology for determining gob permeability distributions and its application to reservoir modeling of coal mine longwalls. In Proceedings of the SME Annual Meeting, Denver, CO, USA, 25-28 February 2007. 
21. Pappas, D.M.; Mark, C. Behavior of Simulated Longwall Gob Material; Report of Investigation; RI-9458; US Department of the Interior, Bureau of Mines: Washington, DC, USA, 1993.

22. Draft Environmental Impact Statement/Subsidence. Appendix D Subsidence. Available online: http:/ / www.blm.gov/style/medialib/blm/co/programs/land_use_planning/rmp/red_cliff_mine/ documents /draft_eis/volume_ii.Par.19028.File.dat/Appendix_D_Subsidence.pdf (accessed on 15 October 2016).

23. Theory of Earth Pressure and Bearing Capac. Available online: http://nptel.ac.in/courses/105101083/ download/lec7.pdf (accessed on 15 October 2016).

24. Jiang, J.Q. Stress and Movenment of Surrounding Rock around the Stope; China Coal Industry Publishing House: Beijing, China, 1993; pp. 15-75.

25. Bai, Q.S.; Tu, S.H.; Yuan, Y.; Wang, F.T. Back analysis of mining induced responses on the basis of goaf compaction theory. J. China Univ. Min. Technol. 2013, 42, 355-362, 369.

26. Ju, M.H.; Li, X.H.; Yao, Q.L.; Li, D.W.; Chong, Z.H.; Zhou, J. Numerical investigation into effect of rear barrier pillar on stress distribution around a longwall face. J. Cent. South Univ. 2015, 22, 4372-4384. [CrossRef]

27. Itasca. Fast Lagrangian Analysis of Continua User's Guide; Itasca Consulting Group Inc.: Minneapolis, MN, USA, 2005.

28. Salamon, M.D.G. Mechanism of caving in longwall mining. In Rock Mechanics Contributions and Challenges, Proceedings of the 31st US Symposium; CRC Press: Golden, CO, USA, 1990; pp. 161-168.

29. Wilson, A.H. Stress and stability in coal ribsides and pillars. In Proceedings of the First International Conference on Ground Control in Mining; West Virginia University: Morgantown, WV, USA, 1981; pp. 1-12.

30. Peng, S.S. Longwall Mining, 2nd ed.; West Virginia University: Morgantown, WV, USA, 2006.

31. Wang, P.F.; Zhao, J.L.; Feng, G.R.; Wang, Z.Q. Improving stress environment in development entries through an alternate longwall mining layout. Arab. J. Geosci. 2018, 11, 44. [CrossRef]

32. Zhao, J.L.; Wang, P.F.; Su, Y. An Innovative Longwall Mining Technology in Tangshan Coal Mine, China. Minerals 2017, 7, 14. [CrossRef]

33. Zhang, J.W.; Wang, J.C.; Wei, W.J.; Chen, Y.; Song, Z.Y. Experimental and Numerical Investigation on Coal Drawing from Thick Steep Seam with Longwall Top Coal Caving Mining. Arab. J. Geosci. 2018, 11, 96. [CrossRef] 